Discussion Papers

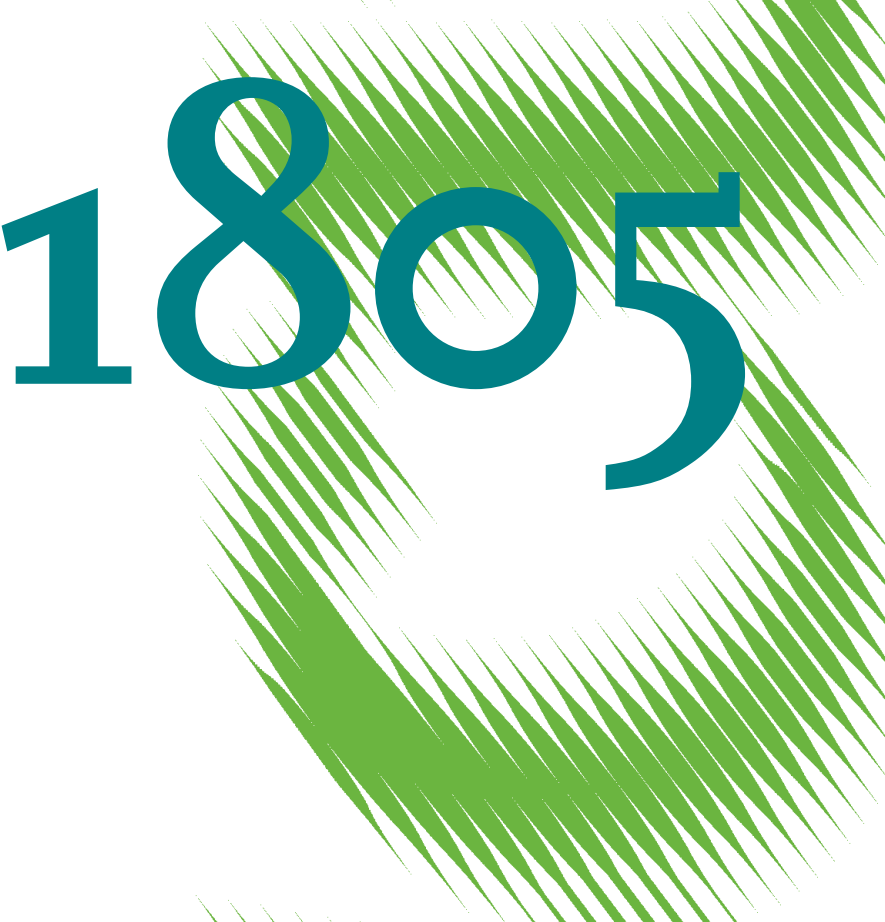

Does the German Minimum Wage Help Low Income Households?

Evidence from Observed Outcomes and the Simulation of Potential Effects 
Opinions expressed in this paper are those of the author(s) and do not necessarily reflect views of the institute.

IMPRESSUM

(C) DIW Berlin, 2019

DIW Berlin

German Institute for Economic Research

Mohrenstr. 58

10117 Berlin

Tel. +49 (30) $89789-0$

Fax +49 (30) $89789-200$

http://www.diw.de

ISSN electronic edition 1619-4535

Papers can be downloaded free of charge from the DIW Berlin website:

http://www.diw.de/discussionpapers

Discussion Papers of DIW Berlin are indexed in RePEc and SSRN:

http://ideas.repec.org/s/diw/diwwpp.html

http://www.ssrn.com/link/DIW-Berlin-German-Inst-Econ-Res.html 


\title{
Does the German Minimum Wage Help Low Income Households? Evidence from Observed Outcomes and the Simulation of Potential Effects
}

\author{
Teresa Backhaus*, Kai-Uwe Müller
}

May 28, 2019

\begin{abstract}
Does the federal minimum wage in Germany introduced in 2015 improve the income situation of low income households and reduce in-work poverty? Previous literature on its distributional impact was either focused on earnings and hourly wages (e.g. Caliendo et al., 2017), or is based on ex-ante simulations (e.g. Müller and Steiner, 2013). This paper provides systematic descriptive ex-post evidence on the distributional implications of the German minimum wage on wages and disposable household incomes as well as some underlying mechanisms.

We analyze various measures of hourly wage and disposable household income distributions, both, for the group of affected individuals and the entire population. Most approaches identify individuals affected by the minimum wage based on pre-reform wages ignoring large job fluctuations and measurement error at the bottom of the wage distribution. In contrast, we define the group of affected by people's relative position in the wage distribution in each respective year. Full compliance scenarios are simulated at the actual and markedly higher minimum wage levels to interpret observational outcomes and gauge the redistributive potential of the minimum wage.

We find evidence for wage increases at the bottom of the wage distribution. Effects on wage inequality are limited because of non-compliance, difficulties in hourly wage measurement in certain types employment, and unequal wage growth across the distribution. Confirming previous simulation evidence the minimum wage proves to be an ineffective tool for the redistribution of disposable household incomes. Overall inequality has even increased slightly as incomes of poor households grew below average. Affected households are not found primarily at the bottom, but rather in the middle of the income distribution. Working hours of individuals and earnings of other members in households affected by the minimum wage decreased. Benefit withdrawal is of minor importance as welfare transfers and top-up benefits were only marginally reduced by the minimum wage.
\end{abstract}

Keywords: minimum wage; wage distribution; income distribution

JEL classification: J31, D31, J03

\footnotetext{
* Corresponding author, Social Science Research Center Berlin (WZB), Reichpietschufer 50, 10785 Berlin, fon: +49 3025491 411, fax: +49 3025491 423, mail: teresa.backhaus@wzb.eu

¥ German Institute for Economic Research Berlin (DIW Berlin), Mohrenstr. 58, D-10117 Berlin, fon: +49 3089789 154, fax: +49 3089789 114, mail: kmueller@ diw.de
} 



\section{Introduction}

One central argument for the introduction of a statutory minimum wage in Germany was the rising income inequality. It has been argued that employees at the bottom of the income distribution often require top up benefits to cover their daily expenses. The fact that people who are in regular work cannot afford their basic standard of living has been perceived as a particular injustice. That is why an explicit political goal (renewed in the coalition agreement of the current government) is that employees working full-time should under no circumstances depend on welfare transfers. As a consequence the minimum wage was introduced to serve as a redistributive tool for reducing inequality in earnings and income. To this date the empirical literature on the distributional impact of the minimum wage in Germany either focuses on earnings and hourly wages (Caliendo et al., 2017) only, or is based on ex ante simulation studies that rely on assumptions like full compliance or no spillovers (Müller and Steiner, 2013; Brenke and Müller, 2013).

This paper provides first empirical evidence on the distributional implications of the German minimum wage on earnings and disposable household incomes. We address a number of research questions that entail different policy implications for the implementation and administration of minimum wages. Since a significant wage effect is a prerequisite for a pass-through to incomes, we investigate, first, the impact of the minimum wage on wages with a particular focus on eligible employees at the bottom of the distribution. Second, we analyze the impact of the minimum wage on the distribution of disposable incomes: Can we confirm the results of previous simulation studies, which found substantially smaller distributional effects on net incomes than on gross wages? In this context we also investigate specific redistributive policy goals: Did the minimum wage decrease prevalence and amount of top-up benefits (Aufstocker) and reduce the dependence on social welfare? Third, we gather evidence on various underlying mechanisms that could explain the distributional consequences of the minimum wage for household incomes beyond non-compliance and measurement problems in the data. For this we investigate the position of low-wage earners across the distribution of disposable household incomes, benefit withdrawal through the tax and welfare system, changes in the structure and incidence of low wage employment as well as adjustments in the working hours of affected employees.

There are no convincing control groups for the statutory minimum wage in Germany (Allegretto et al., 2017; Neumark, 2018; Caliendo et al., 2018). Thus, we refrain from a treatment/control group based research design and do not make strong causal claims. We gather descriptive evidence about the actual situation of individuals and households that were targeted by the reform by drawing a comprehensive distributional picture for affected people and the entire population on the basis of different moments of the hourly wage and household income distributions as well as various inequality measures. Based on the most recent distribution of the German Socio-Economic Panel (SOEP) we construct a consistent panel of individuals and households between 
2012 and 2016. A particular focus is on people eligible for the minimum wage. We systematically compare observational outcomes over time and investigate whether the minimum wage introduction produced noticeable breaks in the data. For purposes of comparison we also simulate two full compliance scenarios: one with the statutory minimum wage level of $8.50 €$ per hour and another with much higher level of $12 €$ per hour that has been repeatedly proclaimed by the Social Democratic Party and the labor unions (Frankfurter Allgemeine, 2018; Zeit Online, 2019). These simulations serve as (ceteris paribus) upper-bound benchmarks for the full potential of the minimum wage when we discuss changes in the incomes based on actual earnings.

In contrast to previous studies we determine "affected" employees and households by their eligibility status and relative position in the hourly wage distribution. Eligibility depends on their employment state according to the minimum wage law. We define those people as affected whose wage in a respective year belongs to the same share of the wage distribution as the group of people who earned less than the introduction minimum-wage-level prior to the reform. ${ }^{1}$ More precisely, we look at the bottom $11 \%$ of employees that would be eligible for the minimum wage law. An advantage of this approach is that it takes account of the high fluctuation at the bottom end of the wage distribution and consistently focuses on the lowest wages. ${ }^{2}$ To calculate disposable household incomes we use a tax-transfer-simulation-model (Steiner et al., 2012).

We find evidence for wage increases at the bottom end of the wage. However, changes lie substantially below the potential of the minimum wage under full compliance which points to implementation problems regarding compliance and measurement of hourly wages. Moreover, the minimum wage proves to be a poor redistributive tool with respect to disposable household income. Confirming ex-ante studies, we do not find affected households benefiting much from the reform. Income inequality and poverty even increased slightly in the years after the minimum wage introduction, since disposable income at the bottom end grew much less than on average. This finding also holds under full compliance and in a scenario with a markedly higher minimum wage level. There is no evidence for significant employment losses or benefit withdrawal induced by the minimum wage. The most important mechanisms for a limited passthrough to low incomes is that low wage earners are spread over the income distribution and face often very insecure employment conditions.

The remainder of this paper is structured as follows: Section 2 discusses our contribution to the distributional minimum wage literature. Section 3 sketches institutional details of the German minimum wage. Section 4 informs about our data set and methodological approach. Section 5 provides empirical results on wages, disposable household incomes, and mechanisms behind the distributional effects (sub-section 5.3). Section 6 concludes.

\footnotetext{
${ }^{1}$ We take 2013 as a reference to avoid potential anticipation effects

${ }^{2}$ Tracking people based on their pre-reform wage would always lead to an upward bias of the overall wage changes due to mean reversion. Other people, who were positioned outside the labor force or at a higher position will have taken their positions within the overall wage distribution.
} 


\section{Literature}

The minimum wage literature has primarily been focused on the consequences for employment (e.g. Neumark and Wascher, 2008; Neumark et al., 2014; Allegretto et al., 2017; or Neumark, 2018). Besides evaluations of sectoral minimum wages (Möller, 2012), several papers for Germany do not find significant effects, or only small negative short-run reductions in employment (Bellmann et al., 2016; Bossler and Gerner, 2016; vom Berge et al., 2016; vom Berge and Frings, 2017; Bruttel et al., 2018; Caliendo et al., 2018; Ahlfeldt et al., 2018). Some marginal jobs have been transformed into regular employment (Garloff, 2017; Bachmann et al., 2017; vom Berge and Weber, 2017).

There is a general consensus in the literature on wages and earnings that a minimum wage is suited to mitigate inequalities at the bottom of the wage distribution. Findings vary with respect to the magnitude of this effect (Autor et al., 2016; Dolton et al., 2012; Stewart, 2012b,a; Autor et al., 2008; Neumark et al., 2004; Dickens and Manning, 2004; Teulings, 2003; Lee, 1999; Machin, 1997; DiNardo et al., 1996). Empirical studies on the question whether a minimum wage initiates spillovers further up into the distribution reach mixed conclusions (Autor et al., 2016; Stewart, 2012b; Dickens and Manning, 2004). Autor et al. (2016) point out that potential mechanisms behind wage spillovers are not fully understood. Applications for Germany include Brautzsch and Schultz (2015), Amlinger et al. (2016), Mindestlohnkommission (2016b), Caliendo et al. (2017), Bossler and Broszeit (2017), Bruttel et al. (2018), and Ahlfeldt et al. (2018) who all confirm wage increases at the bottom of the distribution for Germany. Another important finding is the significant degree of non-compliance.

Minimum wage research on the consequences for disposable incomes, income inequality, and poverty is based on equivalence-weighted incomes at the household level. Redistributive effects are jointly determined by wage and employment changes as well as other factors, e.g. product prices (Lemos, 2008) or interactions with the welfare system (Freeman, 1996). First, (ex ante) simulation studies mimic certain adjustment channels and estimate the consequences for the income distribution. The seminal paper by Johnson and Browning (1983) incorporates interactions with the tax system and employment effects and finds a marginal redistributive impact of the U.S. minimum wage. Burkhauser and co-authors show that the link between low household income and the incidence of low wage employment in the U.S. has loosened (Burkhauser and Finegan, 1989; Burkhauser et al., 1996; Burkhauser and Sabia, 2007; Sabia and Burkhauser, 2010; Neumark, 2015). The minimum wage benefits workers in households above the poverty line relatively more. Macurdy and McIntyre (2001) look at costs induced by higher product prices: Although richer households bear most of the absolute burden, poor households lose more in relative terms because of higher consumption rates. Gosling (1996); Müller and Steiner (2009, 2013), and Campolieti et al. (2012) confirm these findings for the UK, Germany, and Canada.

Second, regression approaches utilize (exogenous) variation in minimum wage 
regulations and estimate effects for various distributional indices, e.g. the incidence or depth of poverty, without referring to particular adjustment mechanisms. Neumark et al. (2005) estimate minimum wage effects on the whole income distribution with kernel density estimators in a difference-in-difference framework and find an increase in poverty. All other empirical ex-post studies utilize panel estimators based on regional variation in federal or state-specific minimum wages over time. A sizable proportion of those studies cannot identify significant effects on the reduction of poverty (Vedder and Gallaway, 2002; Neumark and Wascher, 2002; Burkhauser and Sabia, 2007; Sabia, 2008; Sabia and Burkhauser, 2010; Sabia and Nielsen, 2013). Other studies find moderate, yet statistically significant reductions for the incidence (Addison and Blackburn, 1999; Morgan and Kickham, 2001; Stevans and Sessions, 2001; Gundersen and Ziliak, 2004; DeFina, 2008; Sen et al., 2011) and depth of poverty (Dube, 2018) in the U.S. Neumark et al. (2012) identify a slight poverty-reducing effect of city-wide living wage laws.

Several papers investigate mechanisms that prevent a minimum wage from reaching its redistributive potential, e.g. noncompliance (Brown, 1999; Metcalf, 2008; Mindestlohnkommission, 2016b; Deutscher Bundestag, 2016a,c,b). General equilibrium effects, such as reductions in employment or working hours (Stewart and Swaffield, 2008), are other mechanisms that (in the long-run) mitigate the inequality-reducing effect of minimum wages (Neumark et al., 2004). Minimum wages can also affect schooling (Neumark and Wascher, 1995), firms' profits (Draca et al., 2013), consumer prices (Aaronson and French, 2007), or on-the-job training (Neumark and Wascher, 2001) over the long haul. We draw on some of these mechanisms for the interpretation of our results.

The assessment from the literature on disposable incomes is mixed. The overall redistributive impact of a minimum wage and the relevance of different factors and mechanisms depend on the particular situation. Our study contributes to the distributional minimum wage research by providing first evidence for Germany. This case is interesting as a federal minimum with significant bite is established within the context of a comprehensive welfare state. We draw a multi-dimensional and comprehensive descriptive picture on the redistributive impact of the minimum wage looking at hourly wages, earnings, and disposable household incomes. We establish a link between different approaches by using simulated full-compliance scenarios as upperbound benchmarks for the interpretation of observational outcomes. Moreover we investigate several potential mechanisms (e.g. the position of low wage earners in the income distribution, benefit withdrawal, employment loss or changes, adjustment of working hours and earnings of other household members) that influence the passthrough of wage increases into disposable incomes. 


\section{Minimum wage institutions in Germany}

As codified by the German Minimum Wage Law, the statutory minimum wage of $8.50 €$ per hour at the federal level came into effect on January 1st 2015 (Bruttel et al., 2018). At that time a significant number of collectively agreed sectoral minimum wages had already been put in place and were for many sectors still effective in 2015 and 2016. Examples are, among others, the main construction trade, the roofing sector, or commercial care services. ${ }^{3}$ The sector-specific minimum wages lie above the federal minimum wage or were increased after the minimum wage reform (Amlinger et al., 2016; Möller, 2012). The federal minimum wage is thus not binding in those sectors.

The Minimum Wage Law decrees that the German Minimum Wage Commission consists of employer and employee representatives as well as scientific advisors. Adjustments of the minimum wage level are solely negotiated and recommended by the Minimum Wage Commission and then legally codified by the German parliament. As of January 12017 the minimum wage was raised by $0.34 €$ per hour (Mindestlohnkommission, 2016a). Almost all employees in Germany fall under the legislation of the federal statutory gross minimum wage. During a transitional period that ended in January 2017 exemptions applied to certain sectors with pre-existing sector-specific minimum wages. In addition, permanent exemptions are still in effect for persons below the age of 18, trainees and interns (e.g., students or apprentices completing required or elective internships of up to three months). Long-term unemployed (registered for at least 12 months) are allowed to be paid sub-minimum wages for up to six months. This exception does not play a significant role on the labor market, though (vom Berge et al., 2016). The only exemptions that significantly reduce the number of employees eligible for the minimum wage are trainees and minors. There are, thus, no 'natural' control groups among regularly employed individuals to evaluate the impact of the minimum wage.

The minimum wage is enforced by the German Customs Administration. It regularly conducts inspections of employer firms and enforces compliance with social security laws and the Minimum Wage Law. In case of noncompliance penalties of up to $500,000 €$ can be imposed. However, not least because of personnel shortages due to the refugee crisis enforcement was widely regarded as weak, especially in the first year after the introduction of the minimum wage. For instance, legal proceedings were only initiated in less than 2 out of 100 inspections with an average fine of about $275 €$ (Deutscher Bundestag, 2016c; Burauel et al., 2017).

\footnotetext{
${ }^{3}$ Some of those sector-specific minimum wages were replaced by the statutory minimum wage. As of 1 January 2019 the full list in descending order by minimum wage levels varying from $17.25 €$ per hour to $9.49 €$ per hour and for West and East Germany includes money transports, vocational education and training services, skilled construction workers, commercial cleaning, painting (skilled workers), chimney sweeping, roofing, unskilled construction workers, scaffolding, stonemasonry, electro trade, elderly care, painting (unskilled workers), and temporary agency work (Amlinger et al., 2016).
} 


\section{Data \& methods}

We are interested in the impact of the minimum wage on the overall distributions of hourly wages and disposable household incomes. Notable exemptions from the statutory minimum wage that would constitute 'natural' control groups do not exist. Using the 'regional bite' for identification of distributional effects (see, e.g., Caliendo et al., 2018) also entails a number of problematic assumptions. We therefore follow a basic, descriptive approach that is more transparent. Our empirical analysis is focused on changes in distributions, moments of these distributions, and synthetic distributional measures over time. We check whether these outcomes change significantly after the introduction of the minimum wage. First we use year-to-year changes before the minimum wage was implemented as reference. Second, we compare observed outcomes with simulated outcomes under full compliance to the minimum wage. Third, we investigate specific sub-samples (balanced vs. unbalanced samples, only people affected by the minimum wage) to shut down certain adjustment channels and learn more about the mechanisms behind observed distributional changes over time.

Our empirical analysis is based on SOEP data (sub-section 4.1) and focused on eligible employees (sub-section 4.2). For this we carefully define the group of "affected" employees and households by their eligibility status and their relative position in the hourly wage distribution. Hourly wages are computed by dividing monthly earnings by contractual hours (sub-section 4.3). Disposable household income is calculated on the basis of a tax-transfer-simulation-model (sub-section 4.4). We assume full takeup of benefits and also simulate a scenario where (ceteris paribus) all employers and employees fully comply with minimum wage regulations.

\subsection{Data}

The German Socio-Economic Panel (SOEP) is a representative longitudinal household study that started in 1984. As of 2015 it contains information of roughly 30,000 individuals living in about 15,000 households (Goebel et al., 2018; Wagner et al., 2007). The SOEP provides detailed information on individuals' labor market status, e.g. the type of employment relationship of labor market participants, contractual and actual weekly working hours, and monthly labor earnings. Earnings are distinguished for the primary job and potential side jobs. Moreover, a wide range of individual and household characteristics is available that shed light on the economic and socio-demographic background of the individuals in our samples. This allows us to analyze interactions of the minimum wage with the tax and transfer system in Germany and to simulate disposable incomes at the household level.

We use SOEP version 33.1. ${ }^{4}$ For specific variables, in particular for the labor

\footnotetext{
${ }^{4}$ See https://www.diw.de/sixcms/detail.php?id=diw_01.c.616136.en\#615992, last accessed on 27 May, 2019.
} 
market status, we utilize the SOEP EVA-MIN data set. This is a specific data set that provides information for evaluation purposes and tries to establish certain standards for the preparation of the data to ensure the comparability of the results. ${ }^{5}$

\subsection{Sample construction}

\section{Baseline sample}

Since, the minimum wage is a policy for employees we focus on these individuals and their households in our analysis. Individuals of the following labor market states are included in our sample:

- full-time employees subject to social security contributions,

- part-time employees subject to social security contributions,

- marginally employed people (i.e. those individuals working in so-called mini jobs that are exempted from employees' social security contributions),

- civil servants.

Note that the self-employed and retirees are not eligible for the minimum wage and thus not included in the sample of individuals. In the household sample we exclude households with at least one household member aged over 65 to prevent our results to be influenced by changes in the retirement benefits. For the main analysis we use all sub-samples of the SOEP to keep the sample size roughly constant over time. Frequency weights provided by SOEP are designed to ensure representativeness of the descriptive results.

Over the course of the analysis period the SOEP started oversampling migrants. In addition, overall weights for participants with migration background were adapted to the marginal distribution of the German Microcensus in 2013. Thus, there are potential breaks in the time series unrelated to substantive factors. In particular, we expect outcomes for 2012 and 2013 to be not exactly comparable. Since migrants face different labor market conditions and are over-proportionately affected by the minimum wage, this could have an effect on our measures. Therefore, we provide robustness checks where all observations without German citizenship are excluded.

\section{Eligible employees \& extreme wages}

For the distributional analysis of wages we focus on individuals who were eligible for the minimum wage, i.e. do not belong to exempted groups. There, we systematically exclude individuals from our sample who belong to at least one of the specific groups explicitly exempted from the minimum wage:

\footnotetext{
${ }^{5}$ See https://www.diw.de/en/diw_02.c.219247.en/research_advice/public_finances_ and_living_conditions/the_research_infrastucture_soep/research_projects/ research_projects.htmlid=diw_01.c.526464.en\&skip=20?id=diw_01.c.496963.en for further information, last accessed on 27 May, 2019.
} 
- workers aged under 18 without formal training,

- trainees and certain types of interns,

- long-term unemployed in the first 6 months of a new job and unemployed working,

- employees working in sectors where a tariff agreement regulating sector-specific minimum wages below $8.50 €$ per hour was already in place and is still in a given post-reform year,

- retired individuals.

In order to cope with observations with extreme (and mostly implausible) values in our sample, we censor the bottom and top percentile of the hourly wage, the total wage, and the hours distribution by replacing the values below the bottom percentile and above the top percentile with the threshold value of the respective percentile. This is in line with the censoring procedure in other studies (see, e.g., Caliendo et al., 2018, 2017). ${ }^{6}$

\section{Definition of people affected by the minimum wage}

In most evaluation studies individuals "affected" by the minimum wage are defined as those employees earning an hourly wage below the minimum wage threshold before its introduction or increase. ${ }^{7}$ There is a substantial problem attached to this approach that is rarely discussed in the literature. In the bottom parts of the wage distribution there is a lot of year-to-year fluctuation between jobs. As a result hourly wages of lowwage employees vary substantially between years even in the absence of any minimum wage reforms. This fluctuation can be illustrated by looking at pre-reform years in Germany. A significant share (more than $40 \%$ ) of people working in a jobs paying below the minimum wage in 2012 earn a wage above the minimum wage threshold in the following year (Table 1). Even more than half of them get an hourly wage above the minimum wage another year later.

Table 1: Employees with wages below $8.50 €$ per hour in 2012 (only individuals eligible for the minimum wage)

\begin{tabular}{cccc}
\hline \hline Year & Share with wage $>\mathbf{8 . 5 0 €}$ per hour & CI & Observations \\
\hline 2012 & 0.000 & {$[0.000,0.000]$} & 551 \\
2013 & 0.424 & {$[0.357,0.491]$} & 551 \\
2014 & 0.544 & {$[0.478,0.609]$} & 551 \\
\hline \hline
\end{tabular}

Notes: Bootstrapped 95\% confidence intervals (CI) in parentheses.

Source: SOEP, waves 2012-2014; own calculations.

Aside from potential reporting error this pattern is in many instances also driven by job changes. The share of transitions to a new job is particularly high in the lower

\footnotetext{
${ }^{6}$ Müller and Steiner (2013) or Brenke and Müller (2013), e.g. eliminated all observations with hourly wages below 3 and above $150 €$ per hour.

${ }^{7}$ Recent applications for Germany that follow this approach are, e.g., Caliendo et al. $(2018,2017)$ or Bossler and Gerner (2016).
} 
deciles of the wage distribution: According to our sample $40 \%$ of employees in the bottom decile and $35 \%$ of employees in the second decile changed jobs in a time interval of four years before the minimum wage was introduced (Table 2).

Table 2: Share of job individuals that changed jobs by deciles of the hourly wage distribution, years 2011-2014, pooled

\begin{tabular}{lccc}
\hline \hline Decile & Share of job changes & CI & Observations \\
\hline 1 & 0.39 & {$[0.36,0.41]$} & 5,052 \\
2 & 0.33 & {$[0.31,0.35]$} & 5,047 \\
3 & 0.27 & {$[0.25,0.29]$} & 5,090 \\
4 & 0.23 & {$[0.21,0.25]$} & 5,013 \\
5 & 0.19 & {$[0.17,0.20]$} & 5,114 \\
6 & 0.14 & {$[0.13,0.16]$} & 4,976 \\
7 & 0.12 & {$[0.11,0.14]$} & 5,065 \\
8 & 0.11 & {$[0.10,0.13]$} & 5,032 \\
9 & 0.09 & {$[0.08,0.10]$} & 5,045 \\
10 & 0.11 & {$[0.09,0.12]$} & 5,046 \\
\hline \hline
\end{tabular}

Notes: Bootstrapped $95 \%$ confidence intervals (CI) in parentheses. Source: SOEP, waves 2011-2014; own calculations.

Given those job fluctuations and variation in hourly wages that are not related to the minimum wage, we do not use pre-reform work conditions to define our treatment group. We define as being "affected" by the minimum wage those employees in a certain range at the bottom of the hourly wage distribution who - according to their employment status - are eligible for the minimum wage. The chosen range is determined by the share of eligible employees who earned less than $8.50 €$ per hour prior to the minimum wage reform. We take 2013 as the baseline year to avoid bias through anticipation effects. In $201311 \%$ of eligible employees earned less than $8.50 €$. Therefore, we denote the group of employed people who are eligible for the minimum wage and belong to the bottom $11 \%$ of the hourly wage distribution of a respective year as affected. That way our analysis consistently focuses on those employees with the lowest earnings in a given year and therefore exactly those individuals who have been targeted by the minimum wage reform.

\subsection{Measurement of hourly wages}

It is crucial for the empirical analysis how hourly wages are defined. The SOEP questionaire does not contain a direct query on hourly wages. Yet, respondents are asked questions, both, about their monthly earnings as well as their contractual and actual weekly hours of work. Based on this information different concepts of hourly wages can be computed (see, e.g., Brenke and Müller, 2013, Caliendo et al., 2017, or Dütsch et al., 2017), where monthly labor earnings are simply divided by weekly working hours extrapolated to a monthly figure. 
We employ the arguably most reliable measure based on contractual working hours that are fixed in the contract the employee signed and do not fluctuate or change in the short-run. Although a minimum wage policy intends that employee's receive the minimum wage for all the hours they work, which would be represented by actual working hours in the SOEP, there are problems attached to this wage concept. Actual working hours are more likely to suffer from measurement error, item non-response, and strong fluctuations and therefore lack precision. Moreover, wages and overtime hours do not have the same reference month in the survey. However, we must keep in mind that many employees supply unpaid overtime hours, which might have increased due to the minimum wage reform. The wage measure based on contractual hours thus represents an upper bound for hourly wages.

\subsection{Simulated outcomes}

\section{Full compliance scenario}

To get a benchmark for the redistributive effects of the minimum wage reform under full compliance, we simulate a basic ceteris paribus scenario: All observed hourly wages below $8.50 €$ are lifted to this threshold in post-reform years. Wages above the minimum wage level and other variables remain unchanged. We abstract from wage spillovers and employment effects. Hence, this scenario serves as an upper bound for the distributional impact of the minimum-wage on wages and income under full compliance. We repeat this exercise for a high-minimum wage scenario of $12.00 €$.

\section{Simulation of household incomes}

Of primary interest is whether the minimum wage reached its goal of improving the living standard of low wage earners as measured by disposable household incomes. Therefore, we consider interactions of the minimum wage with the German tax and transfer system on the basis of a microsimulation model (Steiner et al., 2012 ). The model contains the main features of the German tax and transfer system. Gross household income is composed of earnings from dependent employment, income from capital, property rents and other income. Earnings from dependent employment is the most important income component for the great majority of households.

Taxable income is calculated by deducting various expenses from gross household income and considering joint income taxation for couples. For married spouses, income is taxed jointly based on an income splitting factor of 2. Employees' social security contributions and the income tax are deducted from gross household income and social transfers are added to get net household income. Social transfers include child allowances, child-rearing benefits, educational allowances for students and apprentices, unemployment compensation, the housing allowance, and social assistance. All household incomes are equivalence weighted. 


\section{Empirical findings}

A necessary condition to achieve income redistribution is that the minimum wage has a significant impact on the distribution of gross hourly wages. Therefore our empirical analysis starts with individual wage effects (sub-section 5.1). We then turn to the household level and analyze disposable household incomes and related distributional measures (sub-section 5.2). We consider income changes at different quantiles, various distributional measures, and specific redistributive policy goals like welfare dependence and top-up benefits. Finally, we look more into mechanisms behind the distributional effects of the minimum wage (sub-section 5.3).

\section{$5.1 \quad$ Wage effects}

To start the descriptive analysis of wage effects we look at wage distributions of individuals who are eligible for the minimum wage in the time interval between 2012 and 2016 (Figure 1). There is a small shift to the right of the distributions for all pre-reform years, but after the minimum wage was introduced one can see a distinctly larger increase in wages at the bottom of the distribution for 2015. This increase is persistent in 2016 and continues to shift to the right in the magnitude of the pre-reform years. At the same time, a lot of probability mass remains to the left of the minimum wage threshold of $8.50 €$ per hour (horizontal line) even in 2016. The picture is similar for unweighted distributions (Figure A1 in the Appendix).

Figure 1: Distributions of hourly wages, all eligible employees, 2012-2016

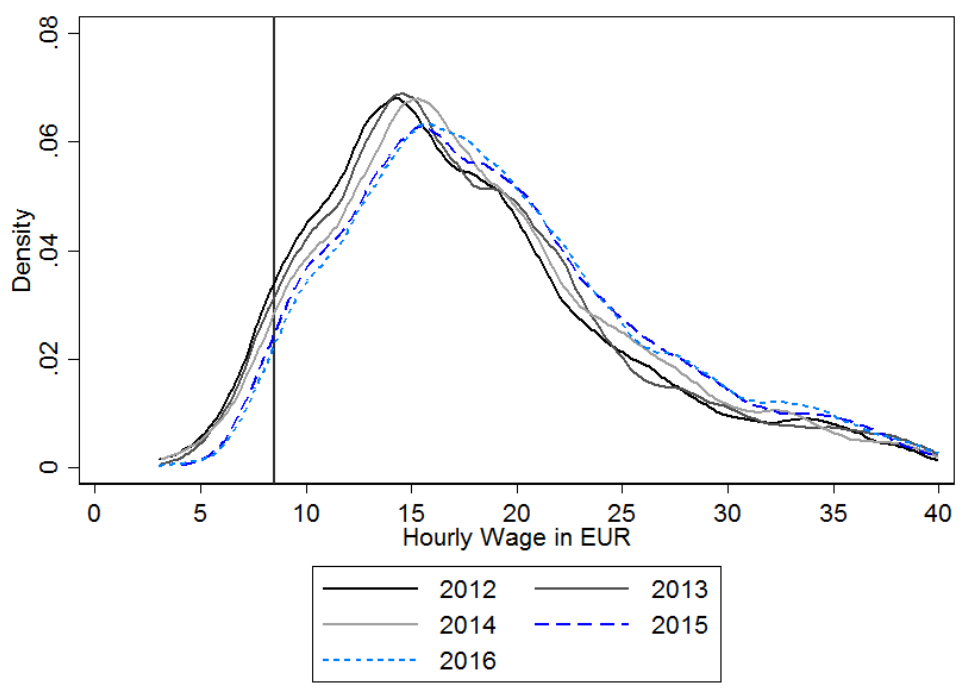

Notes: The vertical line depicts the minimum wage level of $8.50 €$ per hour.

Source: SOEP, waves 2012-2016; weighted; own calculations.

When zooming in on people affected by the minimum wage in the lower parts 
of the distribution, this difference becomes more clearly visible (Figure 2). The spike shifts to the right in 2015 and becomes even more pronounced in 2016. The result pattern is similar when we consider unweighted distributions (Figure A2 in the Appendix) and wages below the 20th quantile (Figures A3 and A4 in the Appendix) for robustness purposes. We do not find systematic changes in contractual working hours of affected employees (Figure A5 in the Appendix).

Figure 2: Distributions of hourly wages, eligible employees affected by the minimum wage: hourly wages below the 11th quantile of the yearly hourly wage distribution, 2012-2016

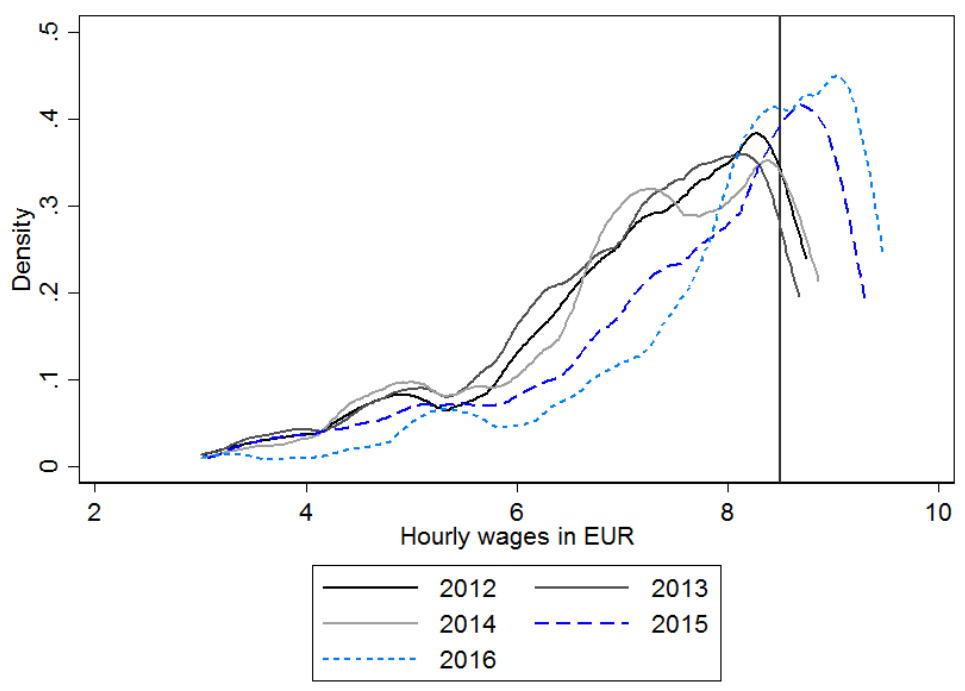

Notes: The vertical line depicts the minimum wage level of $8.50 €$ per hour. Source: SOEP, waves 2012-2016; weighted; own calculations.

A number of points can be taken away from this descriptive analysis of wage distributions: First, (nominal) wage growth occurs in all years of our sample. Second, a clear minimum wage effect becomes visible in density graphs for 2015 and 2016 that is hardly within the range of ordinary wage growth. Third, there is a lot of probability mass still below 8.50 threshold in those graphs for the years after the introduction of the minimum wage. This indicates non-compliance during the implementation of the minimum wage, potentially to a considerable extent (see also Caliendo et al., 2017). This also points to the above-mentioned measurement issues of reporting errors and inconsistencies in the data.

A detailed look at the share of employees in our data who receive wages below the minimum wage helps to shed light on these issues (Table 3). We analyze unbalanced and balanced panels of all and eligible employees to rule out that results are driven by compositional changes. Minimum wage induced job losses would also decrease the share of employees with sub-minimum wages. Note, that the balanced sample consists of individuals with an observed wage in all years. People moving out of employment 
in any period are excluded. Therefore the balanced sample is not representative.

Table 3: Share of employees with hourly wages below $8.50 €$ per hour in $\%$

\begin{tabular}{|c|c|c|c|c|c|c|c|c|}
\hline \multirow[t]{2}{*}{ Year } & \multicolumn{4}{|c|}{ Unbalanced panel } & \multicolumn{4}{|c|}{ Balanced panel } \\
\hline & All & $\mathrm{CI}$ & Eligible & CI & All & CI & Eligible & CI \\
\hline 2012 & 9.2 & {$[8.7 ; 9.7]$} & 10.3 & {$[9.8 ; 10.9]$} & 6.1 & {$[5.4 ; 6.8]$} & 5.9 & {$[5.2 ; 6.7]$} \\
\hline 2013 & 9.2 & {$[8.7 ; 9.6]$} & 10.4 & {$[9.9 ; 11.0]$} & 5.5 & {$[4.9 ; 6.2]$} & 4.8 & {$[4.1 ; 5.5]$} \\
\hline 2014 & 8.8 & {$[8.3 ; 9.3]$} & 10.1 & {$[9.5 ; 10.6]$} & 4.3 & {$[3.7 ; 4.9]$} & 3.7 & {$[3.1 ; 4.3]$} \\
\hline 2015 & 6.6 & {$[6.1 ; 7.0]$} & 7.5 & {$[7.0 ; 8.0]$} & 2.6 & {$[2.1 ; 3.0]$} & 2.1 & {$[1.6 ; 2.6]$} \\
\hline 2016 & 6.1 & {$[5.7 ; 6.6]$} & 6.9 & {$[6.4 ; 7.4]$} & 2.7 & {$[2.2 ; 3.2]$} & 2.1 & {$[1.7 ; 2.6]$} \\
\hline $\mathrm{N}$ & 60,545 & & 53,143 & & 22,055 & & 19,175 & \\
\hline
\end{tabular}

Notes: The balanced panel contains 4411 observations per year and 3835 for those eligible throughout this time. Bootstrapped $95 \%$ confidence intervals (CI) in parentheses.

Source: SOEP, waves 2012-2016; own calculations.

Since employment changes are more frequent at the bottom of the wage distribution, the balanced panel contains more individuals who earn higher wages which explains the smaller shares of individuals with sub-minimum wages. Nevertheless, the trends in the balanced and unbalanced panels are very similar. The share of employees below the threshold is decreasing over time with a particularly strong and significant decrease in 2015 that is persistent in 2016 (Table 3). However, the share remains markedly positive in 2015 (6.6\% in the unbalanced and $2.6 \%$ in the balanced sample). In 2016 this number drops only slightly in the unbalanced samples. This confirms the first impressions from the distributional graphs. It remains unclear to what degree this is a measurement or compliance problem. Evidence on insufficient enforcement of the minimum wage suggest that non-compliance was a significant factor (Caliendo et al., 2017). These findings are robust without weights and for the sub-sample of employees with German citizenship (Tables A1 and A2 in the Appendix).

We now quantify wage changes over the distribution and analyze the distributional effects of the minimum wage based on a sample of individuals eligible for the minimum wage. We introduce a simulated full compliance scenario as a benchmark that ceteris paribus - constitutes an upper bound for wage redistribution. First, we analyze specific quantiles. In 2015 there is a small and significant increase in 5th and 10th percentiles as well as for the median (not in the the 1st percentile). However, changes are small and remain under the minimum wage threshold for the 1st and 5th percentile, as the full compliance scenario illustrates (Table 4). A markedly higher minimum wage level of $12.00 €$ per hour and full compliance would also have an effect on the 10th percentile. These findings are largely robust without weights and for the sub-sample of German nationals (Tables A3 and in A4 the Appendix).

Second, we consider the Atkinson inequality measure, the poverty rate, and other poverty measures from the Foster-Greer-Thorbecke (FGT) class with different weighting parameters (see Cowell 2000, Table 5). In 2014 there is a marked increase in inequality, in particular at the bottom of the distribution. Leaving aside measurement 
Table 4: Percentiles of the hourly wage distribution, only eligible employees

\begin{tabular}{|c|c|c|c|c|c|c|c|c|}
\hline \multirow[t]{3}{*}{ Year } & \multicolumn{6}{|c|}{ Percentiles } & \multicolumn{2}{|r|}{ Median } \\
\hline & \multirow[t]{2}{*}{ P1 } & \multirow{2}{*}{\multicolumn{2}{|c|}{ P5 }} & & \multirow[t]{2}{*}{ P10 } & \multirow[b]{2}{*}{$\mathrm{CI}$} & \multirow{2}{*}{\multicolumn{2}{|c|}{$\mathrm{CI}$}} \\
\hline & & & & $\mathrm{CI}$ & & & & \\
\hline 2012 & 4.66 & {$[4.20 ; 4.72]$} & 7.11 & {$[6.98 ; 7.32]$} & 8.45 & {$[8.28 ; 8.63]$} & 15.17 & {$[14.98 ; 15.54]$} \\
\hline 2013 & 4.72 & {$[4.28 ; 4.95]$} & 7.08 & {$[6.98 ; 7.27]$} & 8.43 & {$[8.18 ; 8.64]$} & 15.15 & {$[14.95 ; 15.44]$} \\
\hline 2014 & 4.72 & {$[4.48 ; 4.81]$} & 7.13 & {$[6.99 ; 7.26]$} & 8.51 & {$[8.26 ; 8.64]$} & 15.69 & {$[15.34 ; 15.95]$} \\
\hline 2015 & 4.72 & {$[4.22 ; 5.31]$} & 7.72 & {$[7.51 ; 7.99]$} & 9.01 & {$[8.77 ; 9.20]$} & 16.33 & {$[16.07 ; 16.61]$} \\
\hline 2016 & 5.31 & {$[5.07 ; 5.91]$} & 8.12 & [7.97;8.32] & 9.11 & [8.99;9.32] & 16.32 & {$[15.95 ; 16.66]$} \\
\hline \multicolumn{9}{|c|}{ Full compliance scenario, minimum wage level: $8.50 €$ per hour } \\
\hline 2015 & 8.50 & & 8.50 & & 9.01 & {$[8.78 ; 9.20]$} & 16.33 & {$[16.05 ; 16.68]$} \\
\hline 2016 & 8.50 & & 8.50 & & 9.11 & {$[8.99 ; 9.27]$} & 16.32 & {$[15.96 ; 16.73]$} \\
\hline \multicolumn{9}{|c|}{ Full compliance scenario, minimum wage level: $12 €$ per hour } \\
\hline 2015 & 12.00 & & 12.00 & & 12.00 & & 16.33 & {$[16.06 ; 16.66]$} \\
\hline 2016 & 12.00 & & 12.00 & & 12.00 & & 16.32 & {$[15.95 ; 16.67]$} \\
\hline
\end{tabular}

Notes: Individual frequency weights used. Bootstrapped 95\% confidence intervals (CI) in parentheses. Source: SOEP, waves 2012-2016; own calculations.

issues this finding clearly goes against anticipation effects. According to the Atkinson index inequality does not change significantly in the years after the reform. Under full compliance we would have observed a significant decrease in wage inequality that would be more pronounced under a high minimum wage - as long as potential employment effects can be ignored (Table 5).

Table 5: Inequality measures, poverty measures for hourly wages, only eligible employees

\begin{tabular}{|c|c|c|c|c|c|c|c|c|}
\hline \multirow{4}{*}{$\begin{array}{l}\text { Year } \\
2012\end{array}$} & \multirow{3}{*}{\multicolumn{2}{|c|}{$\begin{array}{r}\text { Inequality } \\
\text { Atkinson } \\
\text { CI }\end{array}$}} & \multicolumn{6}{|c|}{ Poverty measures } \\
\hline & & & \multirow{2}{*}{\multicolumn{2}{|c|}{$\begin{array}{r}\text { Poverty rate } \\
\mathrm{CI}\end{array}$}} & \multirow{2}{*}{\multicolumn{2}{|c|}{$\begin{array}{r}\text { Poverty gap } \\
\text { CI }\end{array}$}} & \multirow{2}{*}{\multicolumn{2}{|c|}{$\begin{array}{r}\mathrm{FGT}(2) \\
\mathrm{CI}\end{array}$}} \\
\hline & & & & & & & & \\
\hline & 0.20 & {$[0.19 ; 0.21]$} & 13.10 & {$[12.23 ; 14.35]$} & 2.73 & {$[2.50 ; 3.03]$} & 0.94 & {$[0.85 ; 1.08]$} \\
\hline 2013 & 0.20 & {$[0.19 ; 0.21]$} & 13.15 & {$[12.33 ; 14.09]$} & 2.70 & {$[2.46 ; 2.99]$} & 0.90 & {$[0.79 ; 1.06]$} \\
\hline 2014 & 0.21 & {$[0.20 ; 0.22]$} & 15.39 & {$[14.15 ; 16.62]$} & 3.04 & {$[2.76 ; 3.32]$} & 1.02 & {$[0.89 ; 1.14]$} \\
\hline 2015 & 0.20 & {$[0.19 ; 0.21]$} & 13.62 & {$[12.57 ; 14.64]$} & 2.70 & {$[2.41 ; 2.99]$} & 0.89 & {$[0.76 ; 1.03]$} \\
\hline 2016 & 0.19 & {$[0.18 ; 0.21]$} & 14.21 & {$[12.95 ; 15.45]$} & 2.36 & {$[2.09 ; 2.64]$} & 0.72 & {$[0.59 ; 0.84]$} \\
\hline \multicolumn{9}{|c|}{ Full compliance scenario, minimum wage level: $8.50 €$ per hour } \\
\hline 2015 & 0.17 & {$[0.16 ; 0.18]$} & 13.62 & {$[12.58 ; 14.81]$} & 1.41 & {$[1.28 ; 1.52]$} & 0.17 & {$[0.15 ; 0.18]$} \\
\hline 2016 & 0.17 & {$[0.16 ; 0.18]$} & 14.21 & {$[13.04 ; 15.22]$} & 1.35 & {$[1.24 ; 1.47]$} & 0.16 & {$[0.14 ; 0.17]$} \\
\hline \multicolumn{9}{|c|}{ Full compliance scenario, minimum wage level: $12 €$ per hour } \\
\hline 2015 & 0.13 & {$[0.12 ; 0.14]$} & 0.00 & & 0.00 & & 0.00 & \\
\hline 2016 & 0.13 & {$[0.12,0.13]$} & 0.00 & & 0.00 & & 0.00 & \\
\hline
\end{tabular}

Notes: Individual frequency weights used. Poverty line at $60 \%$ of median wage. FGT(2) and FGT(3) denote $F G T(\alpha)=\frac{1}{n} \sum_{i=1}^{q}\left(\frac{z-y_{i}}{z}\right)^{\alpha}$ for $z:=$ poverty line and $q:=$ number of poor, with $\alpha=2$ and $\alpha=3$ respectively. Bootstrapped $95 \%$ confidence intervals (CI) in parentheses.

Source: SOEP, waves 2012-2016; own calculations.

The minimum wage did not significantly reduce the poverty rate based on the 
distribution of hourly wages because the poverty line was above the minimum wage level. Therefore results for the full compliance scenario are similar. A high minimum wage of $12.00 €$ per hour would lift wages of all employed persons above the poverty line (Table 5). Yet, the federal minimum was able to reduce the distance to the poverty line (poverty gap) for the lowest quantiles of the distribution. We find a significant reduction in the poverty gap and the FGT(2) measure after the minimum wage became effective in 2015. A comparison with the simulated full compliance scenario shows that the minimum wage has by far not reached its full potential in reducing wage inequality at the bottom of the distribution. The simulated reduction under full compliance is substantially larger than for the observed outcomes (Table 5). These findings are also robust when we repeat the analysis without weights and for the sub-sample of German nationals (Tables A5 and A6 in the Appendix).

\subsection{Income effects}

We now turn to the question whether the minimum wage improved the situation of low income households and whether the redistributive impact could be significantly higher under full compliance. We calculate disposable household incomes based on microsimulation model. Again, changes over time before and after the introduction of the minimum wage are compared with potential changes under full compliance and for a scenario with a substantially higher minimum wage of $12.00 €$ per hour. Similar to the wage analysis we investigate moments of the income distribution and various distributional measures. In addition, we look at specific minimum wage goals.

\section{Average effects}

Aside from generic income growth, we do not find significant changes in the lower percentiles of the disposable income distribution for households with at least one individual eligible to the minimum wage (Table 6). The only significant increase occurs for mean and median incomes in 2016. This can hardly be driven by the minimum wage introduction. Results for the simulated full compliance scenario indicate that the potential redistributive effect of the minimum wage is not much higher. Neither lower quantiles nor the mean or median of the household income distribution would be lifted significantly. Interestingly, households in the middle of the income distribution would profit more than households at the bottom from a markedly higher minimum wage of $12.00 €$ per hour (Table 6 , lower panel). These findings remain robust with unweighted data and a sub-sample of German nationals (Tables A7 and A8 in the Appendix).

\section{Distributional effects}

Turning to inequality and poverty measures for the income distribution of households observed between 2012 and 2016 largely confirms these findings (Table 7). With flex- 
Table 6: Percentiles of monthly disposable household equivalence income in $€$

\begin{tabular}{cccccccccc}
\hline \hline Year & \multicolumn{2}{c}{ P5 } & \multicolumn{2}{c}{ P10 } & \multicolumn{2}{c}{ Mean } & \multicolumn{2}{c}{ Median } & N \\
& & CI & & CI & & CI & & CI & \\
\hline 2012 & 627 & {$[605 ; 644]$} & 714 & {$[695 ; 732]$} & 1818 & {$[1769 ; 1876]$} & 1491 & {$[1459 ; 1525]$} & 11,305 \\
2013 & 636 & {$[626 ; 648]$} & 716 & {$[705 ; 733]$} & 1850 & {$[1808 ; 1898]$} & 1497 & {$[1465 ; 1528]$} & 12,552 \\
2014 & 664 & {$[650 ; 672]$} & 735 & {$[721 ; 753]$} & 1913 & {$[1862 ; 1972]$} & 1547 & {$[1504 ; 1585]$} & 10,767 \\
2015 & 657 & {$[634 ; 672]$} & 749 & {$[728 ; 768]$} & 1937 & {$[1881 ; 2004]$} & 1575 & {$[1534 ; 1610]$} & 10,559 \\
2016 & 658 & {$[643 ; 669]$} & 754 & {$[730 ; 776]$} & 2136 & {$[2061 ; 2223]$} & 1676 & {$[1637 ; 1729]$} & 10,201 \\
2015 & 659 & {$[639 ; 675]$} & 751 & {$[732 ; 771]$} & 1944 & {$[1887 ; 2002]$} & 1585 & {$[1544 ; 1617]$} & 10,559 \\
2016 & 658 & {$[647 ; 671]$} & 760 & {$[734 ; 784]$} & 2140 & {$[2064 ; 2224]$} & 1685 & {$[1645 ; 1731]$} & 10,201 \\
2015 & 662 & {$[639 ; 673]$} & 756 & {$[729 ; 772]$} & 1966 & {$[1910 ; 2021]$} & 1616 & {$[1582 ; 1647]$} & 10,559 \\
2016 & 659 & {$[648 ; 673]$} & 766 & {$[734 ; 786]$} & 2160 & {$[2086 ; 2257]$} & 1714 & {$[1669 ; 1754]$} & 10,201 \\
\hline \hline
\end{tabular}

Notes: Equivalence weights according to the new OECD scale Household frequency weights by SOEP. Bootstrapped $95 \%$ confidence intervals (CI) in parentheses.

Source: SOEP, waves 2012-2016; all samples included, own calculations.

ible poverty lines for each year poverty increases. Post-reform average and median income growth was higher than for the bottom end of the distribution, especially in 2016. Under full compliance this pattern would have changed only slightly. Overall inequality is not reduced and the poverty measures decrease only mildly in this scenario. Drastically increasing the minimum wage level would not help: Some poverty measures would even increase as the poverty line would also be lifted (Table 7, lower panel).

Table 7: Inequality and poverty measures of net household income

\begin{tabular}{|c|c|c|c|c|c|c|c|c|c|}
\hline \multirow[t]{3}{*}{ Year } & \multicolumn{2}{|c|}{ Inequality } & \multicolumn{7}{|c|}{ Poverty measures } \\
\hline & \multirow{2}{*}{\multicolumn{2}{|c|}{$\begin{array}{r}\text { Atkinson } \\
\text { CI }\end{array}$}} & \multirow{2}{*}{\multicolumn{2}{|c|}{$\begin{array}{c}\text { Poverty rate } \\
\text { CI }\end{array}$}} & \multirow{2}{*}{\multicolumn{2}{|c|}{$\begin{array}{c}\text { Poverty gap } \\
\text { CI }\end{array}$}} & \multirow{2}{*}{\multicolumn{2}{|c|}{$\begin{array}{r}\mathrm{FGT}(2) \\
\mathrm{CI}\end{array}$}} & \multirow{3}{*}{$\begin{array}{c}\begin{array}{c}\text { Poverty } \\
\text { line }\end{array} \\
894.3\end{array}$} \\
\hline & & & & & & & & & \\
\hline 2012 & 0.54 & {$[0.44 ; 0.64]$} & 20.7 & {$[19.6 ; 21.5]$} & 5.0 & [4.6;5.5] & 2.2 & {$[1.9 ; 2.5]$} & \\
\hline 2013 & 0.45 & {$[0.40 ; 0.49]$} & 21.0 & {$[19.7 ; 22.2]$} & 4.9 & {$[4.5 ; 5.3]$} & 2.0 & {$[1.8 ; 2.3]$} & 898.5 \\
\hline 2014 & 0.52 & {$[0.46 ; 0.57]$} & 21.0 & {$[19.3 ; 22.3]$} & 5.0 & {$[4.6 ; 5.5]$} & 2.2 & {$[1.9 ; 2.5]$} & 928.2 \\
\hline 2015 & 0.48 & {$[0.43 ; 0.53]$} & 22.4 & [20.8;23.6] & 5.3 & {$[4.7 ; 5.7]$} & 2.2 & {$[1.9 ; 2.6]$} & 945.2 \\
\hline 2016 & 0.51 & {$[0.45 ; 0.57]$} & 23.4 & {$[22.3 ; 24.9]$} & 5.9 & {$[5.5 ; 6.5]$} & 2.5 & {$[2.2 ; 2.8]$} & 1005.9 \\
\hline \multicolumn{10}{|c|}{ Full compliance scenario, minimum wage level: $8.50 €$ per hour } \\
\hline 2015 & 0.47 & {$[0.41 ; 0.53]$} & 21.8 & [20.1;22.7] & 5.2 & {$[4.7 ; 5.6]$} & 2.2 & {$[1.9 ; 2.5]$} & 951.0 \\
\hline 2016 & 0.51 & {$[0.46 ; 0.57]$} & 23.2 & {$[21.9 ; 24.5]$} & 5.9 & {$[5.4 ; 6.4]$} & 2.5 & {$[2.1 ; 2.8]$} & 1010.9 \\
\hline \multicolumn{10}{|c|}{ Full compliance scenario, minimum wage level: $12 €$ per hour } \\
\hline 2015 & 0.47 & {$[0.42 ; 0.53]$} & 21.9 & {$[20.8 ; 23.2]$} & 5.4 & {$[4.9 ; 5.9]$} & 2.3 & {$[2.0 ; 2.6]$} & 969.9 \\
\hline 2016 & 0.51 & {$[0.45 ; 0.57]$} & 23.5 & {$[22.1 ; 24.6]$} & 6.0 & {$[5.5 ; 6.5]$} & 2.5 & {$[2.2 ; 2.9]$} & 1028.5 \\
\hline
\end{tabular}

Notes: Equivalence weights according to the new OECD scale. Household frequency weights by SOEP. Poverty rate determined by year. $F G T(\alpha)=\frac{1}{n} \sum_{i=1}^{q}\left(\frac{z-y_{i}}{z}\right)^{\alpha}$ for $z:=$ poverty line and $q:=$ number of poor, with $\alpha=2$ and $\alpha=3$ respectively. Bootstrapped $95 \%$ confidence intervals (CI) in parentheses. Source: SOEP, waves 2012-2016; own calculations.

Poverty intensity also rose in the observed data in 2016 . The main reason is that 
the poverty line increased significantly together with the higher parts of the income distribution (Table 7). If the poverty line is held fix to 2014 levels we such an increase cannot be observed (Table A9 in the Appendix). Results based on a fixed poverty line confirm that the maximum redistributive impact of the minimum wage under full compliance would be limited. Hence, in absolute terms households are not worse off, but relative inequality and poverty slightly increased after the introduction of the minimum wage.

Do we find similar patterns when we focus the distributional analysis on households that are directly affected by the minimum wage? We restrict the sample to households where at least one employee earns a hourly wage below the 11th quantile of the wage distribution and analyze poverty for the group of affected households. Mean and median incomes increase in 2016 (Table 8). This is most likely not driven by the minimum wage as we observed a similar trend for the sample of all eligible households. We find a strong increase in the poverty rate and poverty gap in 2015 , even more so in 2016 for households affected directly by the minimum wage. ${ }^{8}$ Successive increases in the poverty lines drive this effect. The minimum wage with full compliance would be able to counteract this trend for the group of affected households. Similarly, lifting the minimum wage to $12.00 €$ per hour further decreases poverty for the group of affected households (Table 8, lower panel). Yet, even for affected household and under full compliance with a $12.00 €$ minimum wage reductions in relative poverty are limited. This underlines that one important reason that the minimum wage does not significantly reduce overall poverty (Table 7 above) is that many low income households are not affected by the minimum wage. All aforementioned distributional results can be reproduced when no weights are applied or a sub-sample of German nationals is used (Tables A10 to A14 in the Appendix).

\section{Specific minimum wage objectives}

Policymakers often state that reducing the dependence on welfare transfers and top-up benefits in addition to labor earnings are primary policy goals of a minimum wage. The simulation results of this paper on transfer income point to a decrease, albeit only to minor reductions in welfare dependency. The share of individuals that are eligible for top-up benefits in our model decreases from $11.3 \%$ in 2014 to $10.8 \%$ in 2015 and $10.5 \%$ in 2016 (Table 9). Under full compliance the reduction would be more distinct and statistically significant. A high minimum wage of $12.00 €$ per hour would ceteris paribus further reduce the share to less than $9 \%$ assuming employees do not become unemployed and welfare-dependent. Based on simulated eligibility the minimum wage is able to somewhat reduce the number of employees receiving top-up benefits. However, it is not very effective as the relatively small reduction for a high minimum wage level shows.

We do not find a similar reduction for average per capita social assistance transfers

\footnotetext{
${ }^{8}$ We use the poverty lines of the unrestricted overall distribution here (see Table 7).
} 


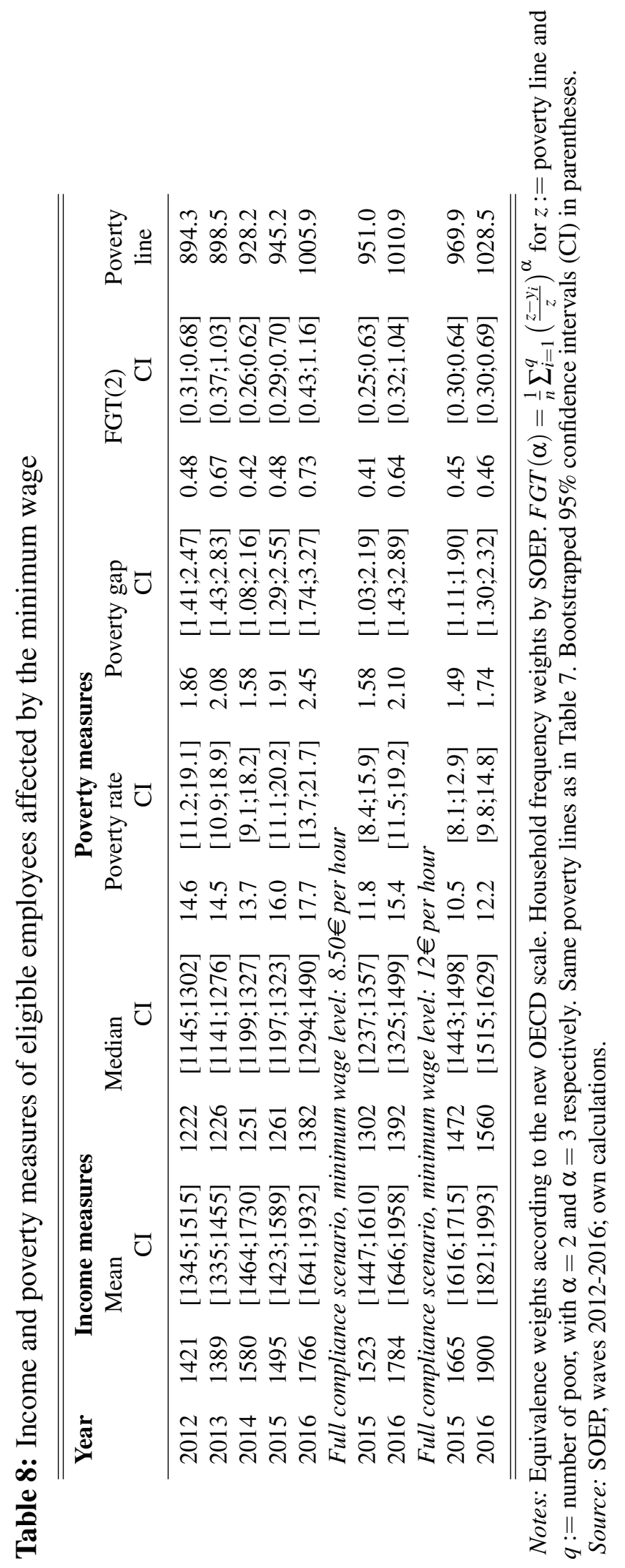


Table 9: Top-up benefits and welfare receipt

\begin{tabular}{|c|c|c|c|c|c|c|}
\hline \multirow[t]{3}{*}{ Year } & \multirow{2}{*}{\multicolumn{2}{|c|}{$\begin{array}{l}\text { Eligible for top-up } \\
\text { benefits (\%) }\end{array}$}} & \multicolumn{4}{|c|}{ Social assistance transfer $€$ per year } \\
\hline & & & & & stated & \\
\hline & & CI & eligibility & $\mathrm{CI}$ & take-up & $\mathrm{CI}$ \\
\hline 2012 & 10.7 & {$[9.8 ; 11.5]$} & 1974.3 & [1866.9;2092.8] & 725.2 & [669.2;793.7] \\
\hline 2013 & 11.3 & {$[10.4 ; 12.1]$} & 2175.6 & [2056.0;2283.1] & 795.3 & [724.3;866.1] \\
\hline 2014 & 11.3 & {$[10.4 ; 12.2]$} & 2075.5 & [1969.1;2207.2] & 826.5 & {$[750.7 ; 910.6]$} \\
\hline 2015 & 10.8 & {$[10.0 ; 11.8]$} & 2186.5 & {$[2055.3 ; 2308.7]$} & 801.4 & [722.4;880.4] \\
\hline 2016 & 10.5 & {$[9.5 ; 11.4]$} & 2122.8 & [1988.6;2248.3] & 871.7 & [793.3;969.2] \\
\hline \multicolumn{7}{|c|}{ Full compliance scenario, minimum wage level: $8.50 €$ per hour } \\
\hline 2015 & 10.0 & {$[9.1 ; 10.8]$} & 2102.4 & {$[1981.0 ; 2235.0]$} & & \\
\hline 2016 & 10.0 & {$[9.1 ; 11.0]$} & 2064.3 & {$[1936.2 ; 2188.2]$} & & \\
\hline \multicolumn{7}{|c|}{ Full compliance scenario, minimum wage level: $12 €$ per hour } \\
\hline 2015 & 8.7 & {$[7.9 ; 9.6]$} & 2005.0 & {$[1884.7 ; 2139.4]$} & & \\
\hline 2016 & 8.9 & {$[8.1 ; 9.8]$} & 1976.5 & {$[1859.8 ; 2116.5]$} & & \\
\hline
\end{tabular}

Notes: Equivalence weights according to the new OECD scale. Household frequency weights used. Bootstrapped $95 \%$ confidence intervals (CI) in parentheses.

Source: SOEP, waves 2012-2015; own calculations.

that are simulated on the basis of observed earnings in the post-reform years. Social assistance even increased in 2015. This seems to be in the realm of yearly fluctuations as the time series for the pre-reform years shows (Table 9). There is, however, a moderate reduction in the amount of social assistance transfers under full compliance. The effects become larger under a high minimum wage of $12.00 €$ per hour. Overall, this confirms the findings for top-up benefits. The minimum wage is able to reduce welfare dependence, but is not a very effective policy tool in this regard. Results can be reproduced without weights and the sub-sample of German nationals (Tables A15 and A16 in the Appendix).

Our simulations represent benefit eligibility only. Eligibility is a valid indicator for the actual neediness of households. This is what policymakers should be concerned with. Whether those benefits are actually taken up is a different story (Bruckmeier et al., 2014). Figures based on stated take-up from the SOEP show a positive trend between 2012 and 2016 (Table 9). There is a small, albeit insignificant, dip in 2015 after the minimum wage introduction. We complement this part of the analysis with administrative statistics on welfare receipt and top-up benefits (Figure 3). The unsmoothed monthly time series exhibit longer, business cycle related trends and seasonal patterns. There are no visible breaks after the minimum wage introduction in 2015 (depicted by the vertical line in the graph), neither in overall unemployment assistance benefit receipt, nor in the receipt of top-up benefits. This confirms our findings that the minimum wage had at best only a marginal effect on the reduction of top-up benefits and overall welfare receipt (see also Bruckmeier and Wiemers, 2015; Mindestlohnkommission, 2016b). 
Figure 3: Employable welfare recipients, top-up benefits, and unemployment assistance benefits, 2005-2018

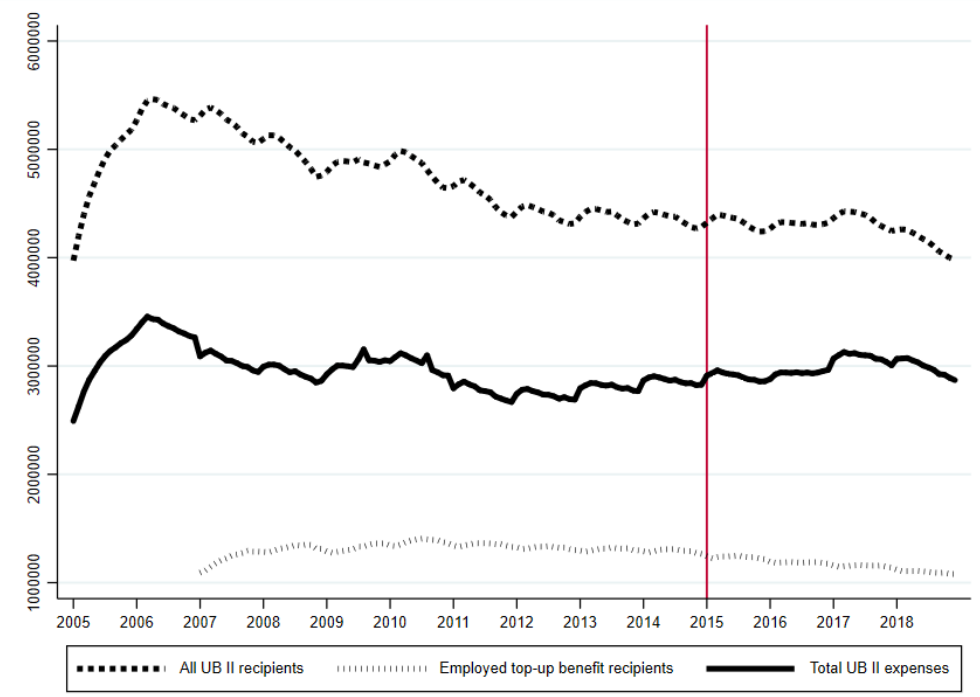

Notes: The vertical line depicts the minimum wage introduction in 2015; total UB II benefits in $1000 €$. Source: Federal employment agency, monthly data 2005-2018; own calculations.

\subsection{Mechanisms}

Which mechanisms are behind the negligible impact the minimum wage has on the income distribution? We showed that there is a small reduction in welfare receipt for affected individuals and households. However, a substitution of welfare transfers by higher wages does not seem to be a dominant factor as the time series of administrative statistics on unemployment assistance benefits that are smooth around the minimum wage introduction indicate. We therefore investigate alternative channels that are responsible for a limited pass-through of wage increases to disposable incomes. First, we analyze the distribution of affected individuals and income changes across disposable household incomes. Second, we check whether whether the employment structure of affected individuals changes. Third, we analyze whether higher wages of affected individuals lead to labor supply adjustments of other household members by tracking the group of individuals with sub-minimum wages in 2014 over time.

\section{Affected individuals over the distribution of disposable household incomes}

The highest share of households with at least one employee affected ${ }^{9}$ by the minimum wage varies around $20 \%$ and can be found in the third decile of the household income distribution (Table 10).

\footnotetext{
${ }^{9}$ We use the definition from above and take employees in the bottom $11 \%$ of the hourly wage distribution of any given year as being affected by the minimum wage (sub-section 4.2 above).
} 


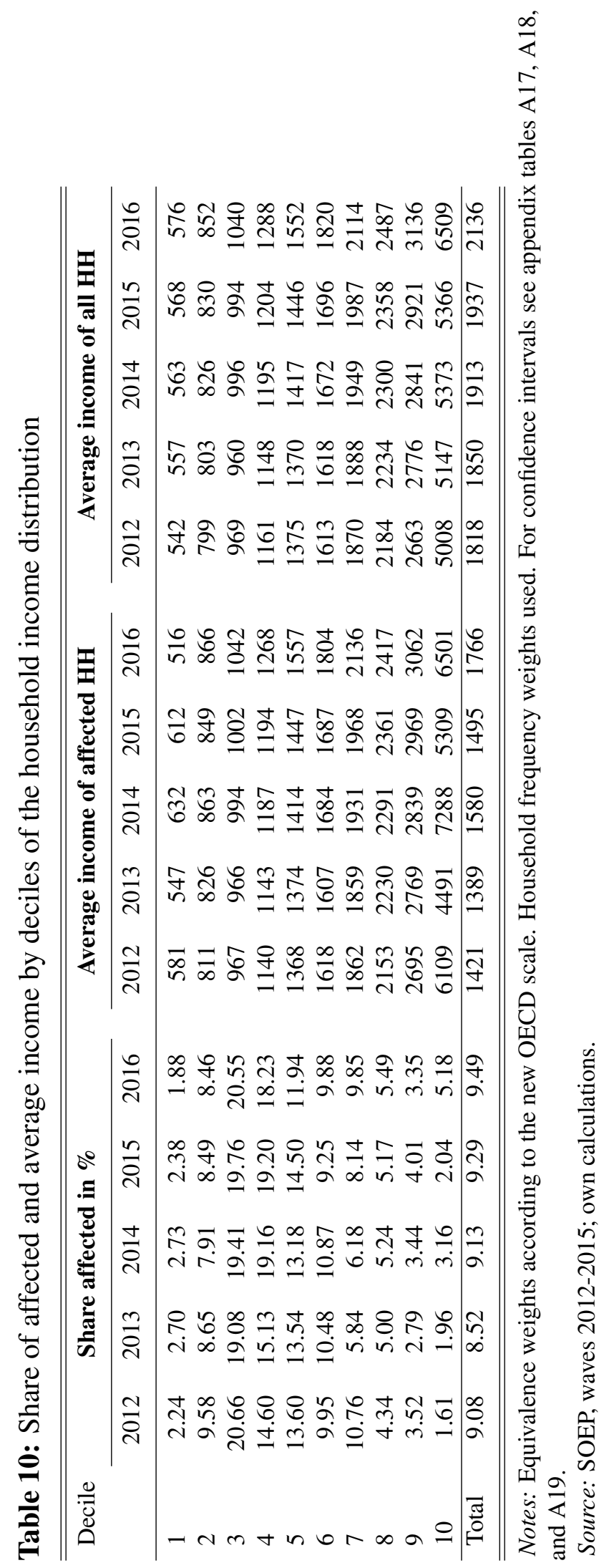


The share is less than half the size in the second and almost negligible in the first decile. On the other hand, shares of affected households vary between $10 \%$ and $20 \%$ up in the 4th and 5th deciles and still reach roughly $10 \%$ in the 6th and even in the 7 th decile. This distribution of affected households is stable over time and consistent with the distributional minimum wage literature. Previous studies for various countries point out that the correlation between gross hourly wages and disposable household incomes is limited (Neumark, 2015; Müller and Steiner, 2013; Burkhauser and Finegan, 1989; Johnson and Browning, 1983). Low-wage employees often provide only the secondary wage earnings to overall household incomes. Various types of welfare transfers can also contribute to this weak relationship between the hourly wage and net income distributions. In terms of average income changes no clear picture emerges for affected households when compared to all households across deciles of the household income distribution. The pattern of income changes among affected households is relatively similar to overall changes by deciles. The marked increase in household incomes between 2015 and 2016, i.e. in the second year after the introduction of the minimum wage, is particularly driven by all deciles above the median.

\section{Changes in the employment structure of affected individuals}

Changes in the employment structure of affected individuals are another potential mechanism that determines the degree of pass-through of wage adjustments to household incomes. This could be part of the explanation why increases in gross earnings do not show in incomes of those households affected by the minimum wage. Adjustments in the employment structure are rather small overall. We observe a decrease in marginal and an increase in part-time employment as well as a slight increase in median working hours in 2015, partially also in 2016 (Table11). ${ }^{10}$ These changes are consistent with previous evidence pointing towards some transformation of marginal jobs into part-time employment (Garloff, 2016, 2017; Bachmann et al., 2017; vom Berge and Weber, 2017).

Large shares of low-wage employees work in the trade, service, and manufacturing sectors. The only persistent changes in sector shares after the minimum-wage introduction are an increase in the construction sector and a decrease in the manufacturing, and maybe in the energy and banking sectors among the bottom $11 \%$ of employees. Results are similar without using weights (Table A20 in the Appendix).

\section{Tracking of affected individuals over time}

We discussed the considerable volatility in employment conditions at the bottom of the hourly wage distribution (sub-section 4.2 above). This is one important reason why we

\footnotetext{
${ }^{10}$ Being conditional on employment, these results do not contradict negative employment effects found by other papers (Bossler and Gerner, 2016; vom Berge et al., 2016; vom Berge and Frings, 2017).
} 
Table 11: Eligible individuals in the bottom $11 \%$ of the hourly wage distribution

\begin{tabular}{lrrrrr}
\hline \hline & $\mathbf{2 0 1 2}$ & $\mathbf{2 0 1 3}$ & $\mathbf{2 0 1 4}$ & $\mathbf{2 0 1 5}$ & $\mathbf{2 0 1 6}$ \\
\hline Threshold wage in $€$ & 8.74 & 8.67 & 8.86 & 9.31 & 9.47 \\
Employment categories in \% & & & & \\
- full time & 55.11 & 54.60 & 50.62 & 53.75 & 51.22 \\
- part time & 17.28 & 18.10 & 17.55 & 19.81 & 23.95 \\
- marginal & 25.42 & 25.33 & 28.88 & 23.74 & 23.19 \\
Contractual working hours per week & & & \\
- mean & 29.74 & 29.53 & 28.41 & 29.19 & 28.28 \\
- median & 33.46 & 32.00 & 29.54 & 31.54 & 30.46 \\
Sectors (in \%) & & & & & \\
Agriculture & 1.22 & 1.70 & 1.36 & 1.70 & 0.32 \\
Energy & 0.34 & 0.43 & 0.28 & 0.21 & 0.06 \\
Manufacturing & 15.00 & 14.72 & 11.51 & 12.76 & 12.84 \\
Construction & 4.83 & 5.77 & 3.99 & 4.18 & 6.68 \\
Trade & 27.62 & 32.48 & 29.65 & 32.50 & 28.9 \\
Transport & 5.13 & 4.63 & 4.32 & 4.25 & 4.62 \\
Bank, Insurance & 1.01 & 1.16 & 0.97 & 0.98 & 0.55 \\
Services & 38.75 & 38.60 & 38.74 & 40.16 & 35.55 \\
\hline Observations & 1400 & 1559 & 1397 & 1345 & 1222 \\
\hline \hline
\end{tabular}

Notes: Affected individuals: bottom $11 \%$ of the hourly wage distribution - reference: share of individuals who earned less than $8.50 €$ per hour in 2013.

Source: SOEP, waves 2012-2016, all samples included, weighted by individual frequency weights; own calculations.

refrain from defining treatment and control groups solely based on individuals' prereform labor market status and wage. Yet, the possibility of tracking people over time is a valuable feature of our panel data for gaining insight into the dynamics of working conditions at the bottom of the wage distribution. First, we follow employees over post-reform years 2015 and 2016 that earned less than $8.50 €$ per hour in the year 2014 before the minimum wage was introduced. Then we repeat the exercise for 2012 as a 'placebo test' and track individuals through 2013 and 2014 before the minimum wage was introduced.

Individuals with wages below 8.50€ per hour in 2014 For this exercise we no longer consider "affected" individuals as defined above (sub-section 4.2), since we need a balanced panel. We therefore consider employees who received wages below $8.50 €$ per hour in their main job in 2014 , the year before the minimum wage introduction. ${ }^{11}$ The first sample considered includes individuals that are at least observed in

\footnotetext{
${ }^{11}$ They are not necessarily actually affected for the reasons pointed out above, e.g. if they change to a new job in 2015 that is not affected by the reform.
} 
2014 and 2015. The second sample includes a balanced panel of individuals who are observed between 2014 and 2016. Figures from the first column that are based on all individuals who had wages below $8.50 €$ per hour in 2014 underline that panel attrition in balanced panels is not selective in terms of wages and contractual hours. We do not use weights in the balanced sample to rule out disproportionately high weights on single observations in these small samples. Between 2014 and 2015 we observe 786 individuals with a share of $76 \%$ women with one fourth becoming unemployed (Table 12). The share of non-employed people is similar in the sample observed between 2014 and 2016. Among the employed only about 71\% keep their job between 2014 and 2015 and about $66 \%$ between 2014 and 2016 .

Table 12: Eligible individuals earning less than $8.50 €$ per hour in 2014

\begin{tabular}{|c|c|c|c|c|c|c|}
\hline \multirow[b]{2}{*}{ Year } & \multirow{2}{*}{$\begin{array}{r}\text { Reference } \\
2014\end{array}$} & \multicolumn{2}{|c|}{ Observed 2014-2015 } & \multicolumn{3}{|c|}{ Observed 2014-2016 } \\
\hline & & 2014 & 2015 & 2014 & 2015 & 2016 \\
\hline Observations & 928 & 786 & 786 & 638 & 638 & 638 \\
\hline \multirow[t]{2}{*}{ Female } & 694 & 593 & 593 & 478 & 478 & 478 \\
\hline & $(75 \%)$ & $(76 \%)$ & $(76 \%)$ & $(75 \%)$ & $(75 \%)$ & $(75 \%)$ \\
\hline Average wages & $821.5 €$ & $808.7 €$ & $830.5 €$ & $817.9 €$ & $839.8 €$ & $962.0 €$ \\
\hline \multirow[t]{2}{*}{ Not employed } & - & - & 196 & - & 162 & 153 \\
\hline & - & - & $(25 \%)$ & - & $(25 \%)$ & $(24 \%)$ \\
\hline Employed & 928 & 590 & 590 & 410 & 410 & 410 \\
\hline (balanced) & & $(75 \%)$ & $(75 \%)$ & $(64 \%)$ & $(64 \%)$ & $(64 \%)$ \\
\hline - Average wages & $821.5 €$ & $849.6 €$ & $1062.7 €$ & $886.2 €$ & $1114.1 €$ & $1256.9 €$ \\
\hline - Contractual hours ${ }^{1}$ & 27.6 & 28.1 & 27.5 & 29.1 & 28.7 & 28.3 \\
\hline - Hourly wages & $6.8 €$ & $6.9 €$ & $9.1 €$ & $6.9 €$ & $9.3 €$ & $10.9 €$ \\
\hline Employed in same & - & 420 & 420 & 271 & 271 & 271 \\
\hline job (balanced) & - & $(71 \%)$ & $(71 \%)$ & $(66 \%)$ & $(66 \%)$ & $(66 \%)$ \\
\hline - Average wages & - & $821.5 €$ & $874.3 €$ & $912.3 €$ & $1084.7 €$ & $1173.1 €$ \\
\hline - Contractual hours ${ }^{1}$ & - & 28.4 & 27.1 & 29.7 & 28.2 & 27.7 \\
\hline - Hourly wages & - & 7.0 & $8.9 €$ & 7.0 & $9.2 €$ & $10.3 €$ \\
\hline Same job and & - & - & $273^{2}$ & - & 200 & $208^{3}$ \\
\hline wage increased & - & - & $(65 \%)^{2}$ & - & $(73 \%)$ & $(76 \%)^{3}$ \\
\hline - Wages others & - & - & $-92.8 €$ & - & $-150.2 €$ & $-85.5 €$ \\
\hline
\end{tabular}

Notes: Individuals affected with an hourly wage below the minimum wage level of $8.50 €$ per hour in 2014 are tracked. In 2014 all observations are employed by construction of the sample. Small numbers of observations are a result of sample restrictions and panel attrition. Individuals without German citizenship excluded (to allow for better comparison with the placebo). ${ }^{1}$ Contractual hours per week. ${ }^{2}$ Among those who stayed in the same job. ${ }^{3}$ Change in total monthly wage wrt. 2014 wages among those who kept the same job since 2014.

Source: SOEP, waves 2014-2016; own calculations.

Both groups, employees and job stayers, experienced substantial wage increases between 2014 and 2015 that continued, to a lesser degree, in 2016. Wage increases are markedly higher for all employed than for job stayers on average and on an hourly basis. Job-to-job transitions are guided by wages (Bagger and Lentz, 2018). More- 
over, we find a reduction in contractual working hours between 2014 and 2015 for all employees that continues in 2016 and is more pronounced for job stayers. Together those changes result in an average wage increase for the whole sample, although $25 \%$ of the sample are not employed. In those households with individuals that kept their job and received a wage raise, other household members decreased their average total wage earnings in 2015 and, to a lesser degree, also in 2016 (Table 12).

Individuals with wages below $8.50 €$ per hour in 2012 ('placebo test') These yearto-year changes are not necessarily driven by the minimum wage, but can also result from regular fluctuation and dynamics on the labor market. Therefore, we repeat the tracking exercise starting in 2012 and follow individuals over pre-reform years. This 'placebo test' is used as reference point for a more nuanced interpretation of our findings in terms of potential minimum wage effects (Table 13).

Table 13: Eligible individuals earning less than $8.50 €$ per hour in 2012

\begin{tabular}{|c|c|c|c|c|c|c|}
\hline \multirow[b]{2}{*}{ Year } & \multirow{2}{*}{$\begin{array}{r}\text { Reference } \\
2012\end{array}$} & \multicolumn{2}{|c|}{ Observed 2012-2013 } & \multicolumn{3}{|c|}{ Observed 2012-2014 } \\
\hline & & 2012 & 2013 & 2012 & 2013 & 2014 \\
\hline Observations & 1131 & 944 & 944 & 790 & 790 & 790 \\
\hline \multirow[t]{2}{*}{ Female } & 833 & 702 & 702 & 589 & 589 & 589 \\
\hline & $(73.7 \%)$ & $(74.4 \%)$ & $(74.4 \%)$ & $(74.6 \%)$ & $(74.6 \%)$ & $(74.6 \%)$ \\
\hline Average wages & $827.2 €$ & $820.8 €$ & $816.6 €$ & $822.4 €$ & $802.8 €$ & $868.8 €$ \\
\hline \multirow[t]{2}{*}{ Not employed } & - & - & 244 & - & 206 & 215 \\
\hline & - & - & $(26 \%)$ & - & $(26 \%)$ & $(27 \%)$ \\
\hline Employed (balanced) & 1,131 & 700 & 700 & 487 & 487 & 487 \\
\hline - Average wages & $827.6 €$ & $870.3 €$ & $1040.0 €$ & $885.1 €$ & $1055.9 €$ & $1165.9 €$ \\
\hline - Contractual hours ${ }^{1}$ & 28.3 & 29.2 & 28.9 & 29.4 & 29.4 & 29.2 \\
\hline - Hourly wages & $6.7 €$ & $6.8 €$ & $8.5 €$ & $6.9 €$ & $8.4 €$ & $9.4 €$ \\
\hline \multirow[t]{2}{*}{ Employed in same job ${ }^{2}$} & - & 532 & 532 & 334 & 334 & 334 \\
\hline & - & $(78 \%)$ & $(78 \%)$ & $(69 \%$ & $(69 \%)$ & $(69 \%)$ \\
\hline - Average wages & - & 886.6 & $979.0 €$ & $907.5 €$ & $1009.8 €$ & $1068.6 €$ \\
\hline - Contractual hours ${ }^{1}$ & - & 29.2 & 28.4 & 29.7 & 28.9 & 28.9 \\
\hline - Hourly wages & - & 6.9 & $8.1 €$ & 7.0 & $8.2 €$ & $8.8 €$ \\
\hline Same job and wage & - & - & 293 & - & 209 & $227^{3}$ \\
\hline increased & - & - & $(55 \%)$ & - & $(63 \%)$ & $(68 \%)^{3}$ \\
\hline - Wages others & - & - & $6.8 €$ & - & $71.8 €$ & $227.7 €$ \\
\hline
\end{tabular}

Notes: Individuals affected with an hourly wage below the minimum wage level of $8.50 €$ per hour in 2012 are tracked. In 2012 all observations are employed by construction of the sample. Small numbers of observations are a result of sample restrictions and panel attrition. Individuals without German citizenship excluded (to allow for better comparison with the placebo). ${ }^{1}$ Contractual hours per week. ${ }^{2}$ Among those who stayed in the same job. ${ }^{3}$ Change in total monthly wage wrt. 2012 wages among those who kept the same job since 2012.

Source: SOEP, waves 2012-2014; own calculations.

The basic patterns for the pre-reform period are similar to the years around the 
minimum wage introduction. The total number of individuals below $8.50 €$ per hour is higher because of generic wage growth over time. The share of people who lose their job from 2012 to 2014 is between $26 \%$ and $27 \%$ and thus slightly higher compared to the post-reform period. Employment volatility is a general problem of low-wage earners. This comparison does not indicate that the minimum wage had substantial negative employment effects. We reiterate the descriptive nature of this evidence as we do not account for other factors determining low-wage employment, most notably business cycle fluctuations. Yet, both tables underline that job-insecurity and nonemployment is an important driver of poverty for people at the bottom of the wage distribution.

There is, however, a marked difference in the growth of average and hourly wages. In addition to the generic year-to-year wage growth driven by job changes, but also within jobs we see a significantly larger wage increase from 2014 to 2015 and also to 2016 when the general minimum wage came into and was in effect compared to the pre-reform years. This confirms our conclusions from above that there is indeed a wage effect at the bottom of the distribution induced by the minimum wage reform (sub-section 5.1 above; see also Caliendo et al., 2017). This effect is more pronounced for job stayers than for all employed. As indicated, individuals who change jobs often realize wage increases independent from labor market regulations. At the same time we also see a more pronounced reduction in contractual working hours in the balanced panels of employees and job stayers after the introduction of the minimum wage. This confirms findings from Stewart and Swaffield (2008); Bellmann et al. (2016); Bossler and Gerner (2016); vom Berge and Weber (2017) and Caliendo et al. (2017) and adds the reduction of working hours, most likely initiated by employers, as another adjustment channel and mitigating factor for a limited pass-through of hourly wages to earnings and income. 


\section{Conclusion}

This paper attempts to close an important gap in the empirical literature on the minimum wage in Germany. This case is of general interest as the introduction of the German minimum wage was one of the largest 'field experiments' in labor and public economics in recent history. A statutory minimum wage with substantial bite, particularly in certain regions and for specific groups of employees, was introduced in a large economy with a generous welfare state. To this day, redistributive motives for the minimum wage are articulated by policy-makers. Yet, credible empirical evidence on the distributional impact of the minimum wage is still lacking for Germany. One important reason is that, apart from few exemptions, the federal minimum wage applies to all employees on the labor market. The are no natural control groups available. In addition, a distributional analysis needs to take potential equilibrium effects into account.

Therefore, we decided to abstain from a causal research design in the narrower sense that is based on treatment and control groups. Accordingly, we do not make strong causal claims in this paper. Instead we provide systematic descriptive evidence in a number of dimensions and paint a comprehensive distributional picture in terms of hourly wages, disposable household income and specific redistributive goals as well as several potential underlying mechanisms. The group of people that are eligible and affected by the minimum wage is followed in a longitudinal perspective between 2012 and 2016. We construct a consistent panel of individuals and households for this period. "Affected" individuals are defined according to their position relative to the cross-sectional wage distribution in a given year. Most other studies determine people affected by the minimum wage solely based on the wage distribution before the reform. This approach is prone to measurement error which - as we showed - can be substantial in widely used survey data as the SOEP. Additional bias can arise from year-to-year job fluctuations that are disproportionately high at the bottom of the wage distribution and lead to movements into and out of the group of potentially affected individuals. We provided evidence for this mechanism.

We found unequivocal evidence for wage increases at the bottom of the hourly wage distribution. The effects lie, however, substantially below the potential the minimum wage would have had under full compliance. This is the main reason for a limited impact on wage inequality. Further, we could confirm results from ex ante simulations and evidence from other countries that the minimum wage is not an effective tool for income redistribution and the reduction of poverty. It is not able to target individuals in needy households. Low wage earners are not concentrated at the bottom of the distribution of disposable household incomes in Germany. They are spread out over the middle and also higher parts of the distribution. We found only limited evidence for the withdrawal of welfare transfers on the basis of simulated eligibility and claims. Administrative statistics on unemployment assistance and top-up benefits ("Aufstocker") receipt indicate that this is not a first order mechanism. We also did not find evidence that the incidence or structure of low wage employment changed significantly as a re- 
sult of the minimum wage. In terms of overall income inequality the situation has even deteriorated after the introduction of the minimum wage as disposable incomes at the bottom end grew slower than average incomes. We showed that a higher minimum wage level of $12 €$ per hour as demanded from certain policymakers would not change these findings at all.

What do our results mean for the future policy discussion about minimum wages? First, we provide further evidence that the minimum wage cannot significantly reduce income inequality and poverty. This holds all the more in comprehensive welfare states with generous social insurance benefits. Fair wages and fair competition on the labor market are more legit and attainable policy goals for a minimum wage. In light of current discussions about substantial increases of the minimum wage level in order to eventually reach these redistributive goals, our findings may serve as a cautionary tale. Second, some of our results point to methodological issues for the analysis of minimum wage effects based on household survey data on earnings and working time. Besides manifest measurement issues in terms of hourly wages, we found substantial year-to-year job and thus wage fluctuations. This can introduce bias in studies relying on a single pre-reform measure of the group affected by the minimum wage. Further efforts should be undertaken to improve the data base on hourly wages in Germany to enable more credible evidence on the empirical effect of the minimum wage. Third, the comparison of observed outcomes with hypothetical upper bound effects in our full-compliance scenario points to a substantial non-compliance problem of the minimum wage in the first two years after introduction. There is need for further action to implement current minimum wage regulations. Yet, it remains unclear to what extent this can be explained by cheating employers and employees exactly. There may be certain areas where defining and measuring hourly wages is inherently problematic. There is need for further research in this area. Fourth, instead of pushing up the minimum wage to much higher levels, our results on underlying mechanisms rather point to severe problems of employability of individuals in low income households as well as discontinuities and job insecurities for low wage earners. There is a glaring need to improve the labor market attachment of individuals in the bottom decile of the income distribution. Moreover, more research and policy action is needed to improve employment conditions of low wage earners beyond their hourly wage. Both would help to decrease income inequality and poverty. 


\section{References}

Aaronson, D. and French, E. (2007). Product Market Evidence on the Employment Effects of the Minimum Wage. Journal of Labor Economics, 25:167-200.

Addison, J. T. and Blackburn, M. L. (1999). Minimum wages and poverty. Industrial and Labor Relations Review, 52(3):393-409.

Ahlfeldt, G. M., Roth, D., and Seidel, T. (2018). The regional effects of germanys national minimum wage. Economics Letters, 172:127-130.

Allegretto, S., Dube, A., Reich, M., and Zipperer, B. (2017). Credible research designs for minimum wage studies: A response to neumark, salas, and wascher. ILR Review, 70(3):559-592.

Amlinger, M., Bispinck, R., and Schulten, T. (2016). The German minimum wage: experiences and perspectives after one year. WSI-Report, 28e(1):1-18.

Autor, D. H., Katz, L. F., and Kearney, M. S. (2008). Trends in u.s. wage inequality: Revising the revisionists. The Review of Economics and Statistics, 90(2):300-323.

Autor, D. H., Manning, A., and Smith, C. L. (2016). The contribution of the minimum wage to us wage inequality over three decades: A reassessment. American Economic Journal: Applied Economics, 8(1):58-99.

Bachmann, R., Dürig, W., Frings, H., Höckel, L. S., and Martinez Flores, F. (2017). Minijobs nach Einführung des Mindestlohns - eine Bestandsaufnahme. RWI Materialien 114, RWI - Leibniz-Institut für Wirtschaftsforschung.

Bagger, J. and Lentz, R. (2018). An Empirical Model of Wage Dispersion with Sorting. The Review of Economic Studies, 86(1):153-190.

Bellmann, L., Bossler, M., Dütsch, M., Gerner, H.-D., and Ohlert, C. (2016). Folgen des mindestlohns in deutschland. betriebe reagieren nur selten mit entlassungen. Technical report, IAB-Kurzbericht No. 18/2016, Institut für Arbeitsmarkt- und Berufsforschung (IAB), Nürnberg.

Bossler, M. and Broszeit, S. (2017). Do minimum wages increase job satisfaction? Micro-data evidence from the new German minimum wage. LABOUR, 31(4):480493.

Bossler, M. and Gerner, H.-D. (2016). Employment effects of the new German minimum wage : evidence from establishment-level micro data. IAB Discussion Paper 201610, Institut für Arbeitsmarkt- und Berufsforschung (IAB), Nürnberg [Institute for Employment Research, Nuremberg, Germany].

Brautzsch, H.-U. and Schultz, B. (2015). Aktuelle Trends: Mindestlohn von 8,50 Euro: Hohe Betroffenheit in arbeitsintensiven Branchen. Wirtschaft im Wandel, 21(1):1-3. 
Brenke, K. and Müller, K.-U. (2013). Gesetzlicher mindestlohn - kein verteilungspolitisches allheilmittel. DIW Wochenbericht, No. 39:3-18.

Brown, C. (1999). Minimum wages, employment, and the distribution of income. In Ashenfelter, O. and Card, D. E., editors, Handbook of Labor Economics, volume 3, pages 2101-2163. Elsevier, Amsterdam et al.

Bruckmeier, K., Müller, G., and Riphahn, R. T. (2014). Who misreports welfare receipt in surveys? Applied Economics Letters, 21(12):812-816.

Bruckmeier, K. and Wiemers, J. (2015). Trotz Mindestlohn: viele bedürftig. Wirtschaftsdienst, 95(7):444-446.

Bruttel, O., Baumann, A., and Dütsch, M. (2018). The new german statutory minimum wage in comparative perspective: Employment effects and other adjustment channels. European Journal of Industrial Relations, 24(2):145-162.

Burauel, P., Caliendo, M., Fedorets, A., Grabka, M. M., Schröder, C., Schupp, J., and Wittbrodt, L. (2017). Minimum wage not yet for everyone: on the compensation of eligible workers before and after the minimum wage reform from the perspective of employees. DIW Economic Bulletin, (49/2017):509-522.

Burkhauser, R. V., Couch, K. A., and Glenn, A. J. (1996). Public policies for the working poor: The earned income tax credit versus minimum wage legislation. Research in Labor Eocnomics, 15:65-110.

Burkhauser, R. V. and Finegan, T. A. (1989). The minimum wage and the poor: The end of a relationship. Journal of Policy Analysis and Management, 8(1):53-71.

Burkhauser, R. V. and Sabia, J. J. (2007). The effectiveness of minimum-wage increases in reducing poverty: Past, present, and future. Contemporary Economic Policy, 25(2):262-281.

Caliendo, M., Fedorets, A., Preuß, M., Schröder, C., and Wittbrodt, L. (2017). The Short-Term Distributional Effects of the German Minimum Wage Reform. IZA Discussion Papers 11246, Institute for the Study of Labor (IZA).

Caliendo, M., Fedorets, A., Preuss, M., Schröder, C., and Wittbrodt, L. (2018). The short-run employment effects of the german minimum wage reform. Labour Economics, 53:46-62.

Campolieti, M., Gunderson, M., and Lee, B. (2012). The (non) impact of minimum wages on poverty: Regression and simulation evidence for canada. Journal of Labor Research, 33(3):287-302.

Cowell, F. A. (2000). Measuring Inequality. Oxford University Press, Oxford, UK. 
DeFina, R. H. (2008). The impact of state minimum wages on child poverty in femaleheaded families. Journal of Poverty, 12(2):155-174.

Deutscher Bundestag (2016a). Finanzkontrolle schwarzarbeit - kontrolle von mindestlöhnen 2015. Technical report, Drucksache 18/7525.

Deutscher Bundestag (2016b). Finanzkontrolle schwarzarbeit: Kontrolle von mindestlöhnen 2016. Technical report, Drucksache 18/11475.

Deutscher Bundestag (2016c). Kontrolle der einhaltung des gesetzlichen mindestlohns. Technical report, Drucksache 18/8513.

Dickens, R. and Manning, A. (2004). Has the national minimum wage reduced UK wage inequality? Journal of the Royal Statistical Society Series A, 167(4):613-626.

DiNardo, J., Fortin, N. M., and Lemieux, T. (1996). Labor market institutions and the distribution of wages, 1973-1992: A semiparametric approach. Econometrica, 64(5):1001-1044.

Dolton, P., Bondibene, C. R., and Wadsworth, J. (2012). Employment, Inequality and the UK National Minimum Wage over the Medium-Term. Oxford Bulletin of Economics and Statistics, 74(1):78-106.

Draca, M., Machin, S., and van Reenen, J. (2013). Minimum wages and firm profitability. American Economic Journal: Applied Economics, 3(1):129-151.

Dube, A. (2018). Minimum Wages and the Distribution of Family Incomes. NBER Working Papers 25240, National Bureau of Economic Research, Inc.

Dütsch, M., Himmelreicher, R., and Ohlert, C. (2017). Zur Berechnung von Bruttostundenlöhnen - Verdienst(struktur)erhebung und Sozio-oekonomisches Panel im Vergleich. SOEPpapers on Multidisciplinary Panel Data Research 911, DIW Berlin, The German Socio-Economic Panel (SOEP).

Frankfurter Allgemeine (2018). "Zwölf Euro Mindestlohn sind angemessen". https://www.faz.net/aktuell/wirtschaft/mehr-wirtschaft/ mindestlohn-olaf-scholz-fuer-12-euro-15866204.html, retrieved 5th May 2019.

Freeman, R. B. (1996). The minimum wage as a redistributive tool. The Economic Journal, 106(436):639-649.

Garloff, A. (2016). Side effects of the new German minimum wage on (un)employment: first evidence from regional data. IAB Discussion Paper 201631, Institut für Arbeitsmarkt- und Berufsforschung (IAB), Nürnberg [Institute for Employment Research, Nuremberg, Germany]. 
Garloff, A. (2017). Side effects of the new German minimum wage on (un)employment, First evidence from regional data - Update. Technical Report No. 4, German Federal Ministry for Economic Affairs and Energy, Discussion Paper.

Goebel, J., Grabka, M. M., Liebig, S., Kroh, M., Richter, D., Schröder, C., and Schupp, J. (2018). The german socio-economic panel (soep). Journal of Economics and Statistics, 0(0):xx-Xx.

Gosling, A. (1996). Minimum wages: Possible effects on the distribution of income. Fiscal Studies, 17(4):31-48.

Gundersen, C. and Ziliak, J. P. (2004). Poverty and macroeconomic performance across space, race, and family structure. Demography, 41(1):pp. 61-86.

Johnson, W. R. and Browning, E. K. (1983). The distributional and efficiency effects of increasing the minimum wage: A simulation. American Economic Review, 73(1):204-211.

Lee, D. S. (1999). Wage inequality in the united states during the 1980s: Rising dispersion or falling minimum wage? The Quarterly Journal of Economics, 114(3):9771023.

Lemos, S. (2008). A survey of the effects of the minimum wage on prices. Journal of Economic Surveys, 22(1):187-212.

Machin, S. (1997). The decline of labour market institutions and the rise in wage inequality in britain. European Economic Review, 41:647-657.

Macurdy, T. E. and McIntyre, F. (2001). Winners and losers of federal and state minimum wages. Technical report, Employment Policies Institute, Washington, D.C.

Metcalf, D. (2008). Why has the british national minimum wage had little or no impact on employment? Journal of Industrial Relations, 50(3):489-512.

Mindestlohnkommission (2016a). Beschluss der Mindestlohnkommission nach $\S 9$ MiLoG.

Mindestlohnkommission (2016b). Erster Bericht zu den Auswirkungen des gesetzlichen Mindestlohns.

Möller, J. (2012). Minimum wages in german industries - what does the evidence tell us so far? Journal of Labour Market Research, 45(3-4):187-199.

Morgan, D. R. and Kickham, K. (2001). Children in poverty: Do state policies matter? Social Science Quarterly, 82(3):478-493. 
Müller, K.-U. and Steiner, V. (2009). Would a legal minimum wage reduce poverty? a microsumulation study for germany. Journal of Income Distribution, 18(2):131151.

Müller, K.-U. and Steiner, V. (2013). Distributional effects of a minimum wage in a welfare state - the case of germany. Technical report, SOEPpapers on Multidisciplinary Panel Data Research No. 617, German Institute for Economic Research (Deutsches Institut für Wirtschaftsforschung, DIW), Berlin.

Neumark, D. (2015). Reducing poverty via minimum wages, alternatives. FRBSF Economic Letter, (2015-38):1-5.

Neumark, D. (2018). The Econometrics and Economics of the Employment Effects of Minimum Wages: Getting from Known Unknowns to Known Knowns. NBER Working Papers 25043, National Bureau of Economic Research, Inc.

Neumark, D., Salas, J. M. I., and Wascher, W. (2014). Revisiting the Minimum WageEmployment Debate: Throwing out the Baby with the Bathwater. Industrial and Labor Relations Review, 67:608-648.

Neumark, D., Schweitzer, M., and Wascher, W. (2004). Minimum wage effects throughout the wage distribution. The Journal of Human Resources, 39(2):425-450.

Neumark, D., Schweitzer, M., and Wascher, W. (2005). The effects of minimum wages on the distribution of family incomes: A non-parametric analysis. The Journal of Human Resources, 40(4):867-894.

Neumark, D., Thompson, M., and Koyle, L. (2012). The effects of living wage laws on low-wage workers and low-income families: What do we know now? IZA Journal of Labor Policy, 1(11):1-34.

Neumark, D. and Wascher, W. (2001). Minimum wages and training revisited. Journal of Labor Economics, 19(3):563-595.

Neumark, D. and Wascher, W. (2002). Do minimum wages fight poverty? Economic Inquiry, 40(3):315-333.

Neumark, D. and Wascher, W. (2008). Minimum Wages. Cambridge University Press, Cambridge/Massachusetts.

Sabia, J. J. (2008). Minimum wages and the economic well-being of single mothers. Journal of Policy Analysis and Management, 27(4):848-866.

Sabia, J. J. and Burkhauser, R. V. (2010). Minimum wages and poverty: Will a $\$ 9.50$ federal minimum wage really help the working poor? Southern Economic Journal, 76(3):592-623. 
Sabia, J. J. and Nielsen, R. B. (2013). Minimum wages, poverty, and material hardship: new evidence from the sipp. Review of Economics of the Household, online first:140 .

Sen, A., Rybczynski, K., and Van De Waal, C. (2011). Teen employment, poverty, and the minimum wage: Evidence from canada. Labour Economics, 18(1):36-47.

Steiner, V., Wrohlich, K., Haan, P., and Geyer, J. (2012). Documentation of the taxbenefit microsimulation model stsm. version 2012. Technical report, DIW Data Documentation No. 63, German Institute for Economic Research (DIW Berlin), Berlin.

Stevans, L. and Sessions, D. (2001). Minimum Wage Policy and Poverty in the United States. International Review of Applied Economics, 15(1):65-75.

Stewart, M. B. (2012a). Quantile estimates of counterfactual distribution shifts and the effect of minimum wage increases on the wage distribution. Journal of the Royal Statistical Society Series A, 175(1):263-287.

Stewart, M. B. (2012b). Wage inequality, minimum wage effects, and spillovers. $O x$ ford Economic Papers, 64(4):616-634.

Stewart, M. B. and Swaffield, J. K. (2008). The Other Margin: Do Minimum Wages Cause Working Hours Adjustments for Low-Wage Workers? Economica, 75(297):148-167.

Teulings, C. N. (2003). The contribution of minimum wages to increasing wage inequality. Economic Journal, 113(490):801-833.

Vedder, R. and Gallaway, L. (2002). The minimum wage and poverty among full-time workers. Journal of Labor Research, 23(1):41-49.

vom Berge, P. and Frings, H. (2017). High-Impact Minimum Wages and Heterogeneous Regions. IZA Discussion Papers 10782, Institute for the Study of Labor (IZA).

vom Berge, P., Klingert, I., Becker, S., Lenhart, J., Trenkle, S., and Umkehrer, M. (2016). Mindestlohnbegleitforschung - Überprüfung der Ausnahmeregelung für Langzeitarbeitslose: Forschungsauftrag des Bundesministeriums für Arbeit und Soziales (BMAS). IAB-Forschungsbericht 201608, Institut für Arbeitsmarkt- und Berufsforschung (IAB), Nürnberg [Institute for Employment Research, Nuremberg, Germany].

vom Berge, P. and Weber, E. (2017). Beschäftigungsanpassung nach mindestlohneinführung minijobs wurden teilweise umgewandelt, aber auch zulasten anderer stellen. Technical report, IAB-Kurzbericht No. 11/2017, Institut für Arbeitsmarktund Berufsforschung (IAB), Nürnberg. 
Wagner, G. G., Frick, J. R., and Schupp, J. (2007). The german socio-economic panel study (soep) - scope, evolution and enhancements. Schmollers Jahrbuch. Journal of Contextual Economics, 127(1):139-169.

Zeit Online (2019). "SPD will 12 Euro Mindestlohn und ein Recht auf 'Home Office'". https://www.zeit.de/news/2019-02/07/ spd-will-12-euro-mindestlohn-und-ein-recht-auf-home-office190207-99-883817, retrieved 5th May 2019. 


\section{Appendix}

\section{Additional figures}

Figure A1: Distributions of hourly wages, all eligible employees - robustness: unweighted, 2012-2016

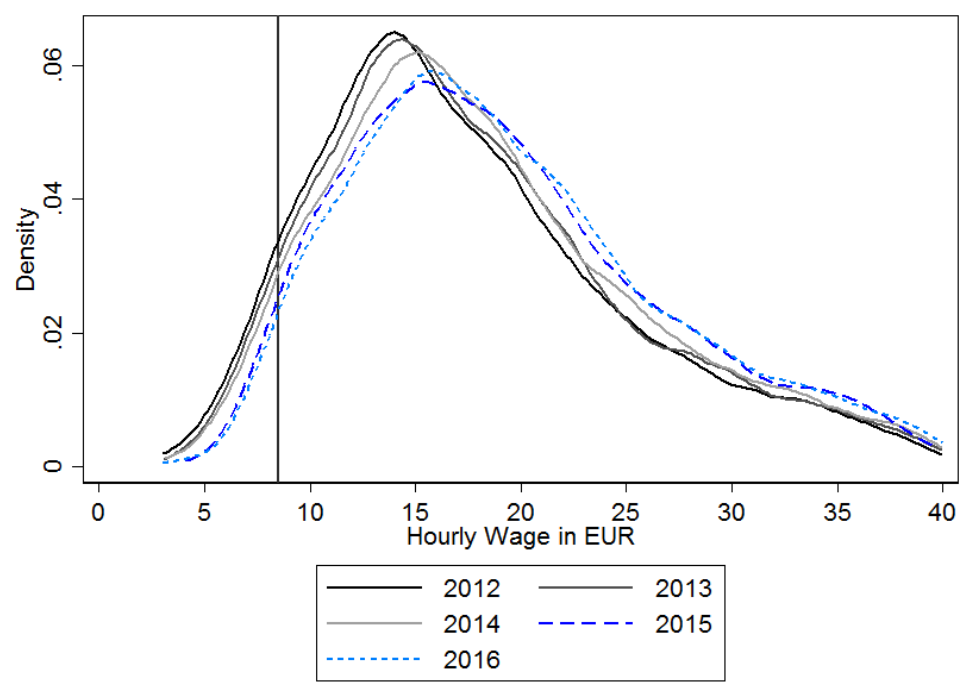

Notes: The vertical line depicts the minimum wage level of $8.50 €$ per hour. Source: SOEP, waves 2012-2016; own calculations. 
Figure A2: Distributions of hourly wages, eligible employees affected by the minimum wage: hourly wages below the 11th quantile of the yearly hourly wage distribution - robustness: unweighted, 2012-2016

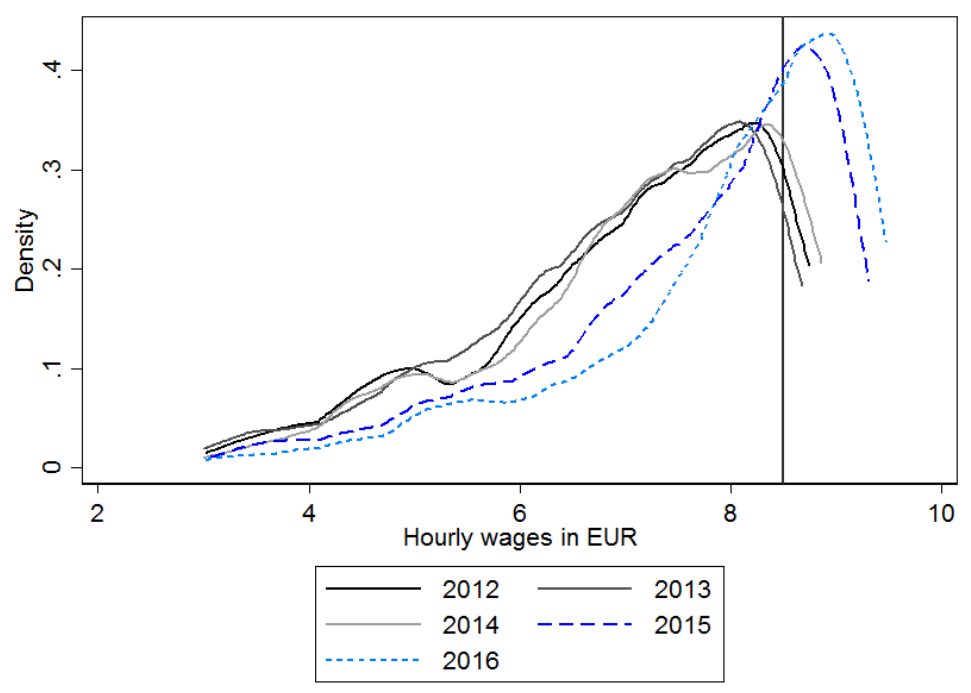

Notes: The vertical line depicts the minimum wage level of $8.50 €$ per hour. Source: SOEP, waves 2012-2016; own calculations.

Figure A3: Distributions of hourly wages, eligible employees affected by the minimum wage - robustness: hourly wages below the 20th quantile of the yearly hourly wage distribution, weighted, 2012-2016

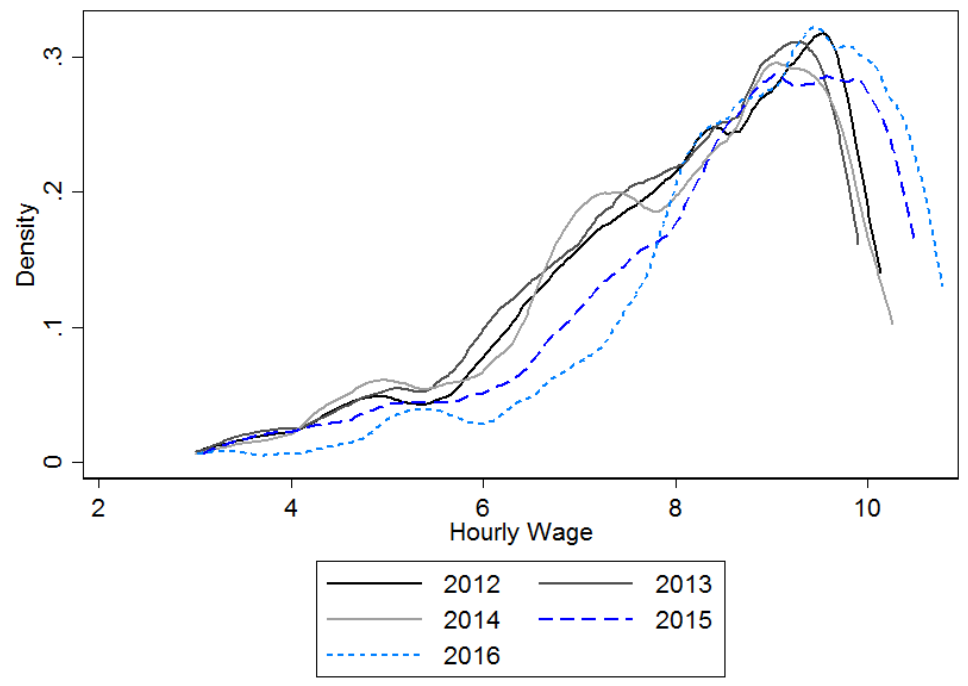

Notes: The vertical line depicts the minimum wage level of $8.50 €$ per hour. Source: SOEP, waves 2012-2016; own calculations. 
Figure A4: Distributions of hourly wages, eligible employees affected by the minimum wage - robustness: hourly wages below the 20th quantile of the yearly hourly wage distribution, unweighted, 2012-2016

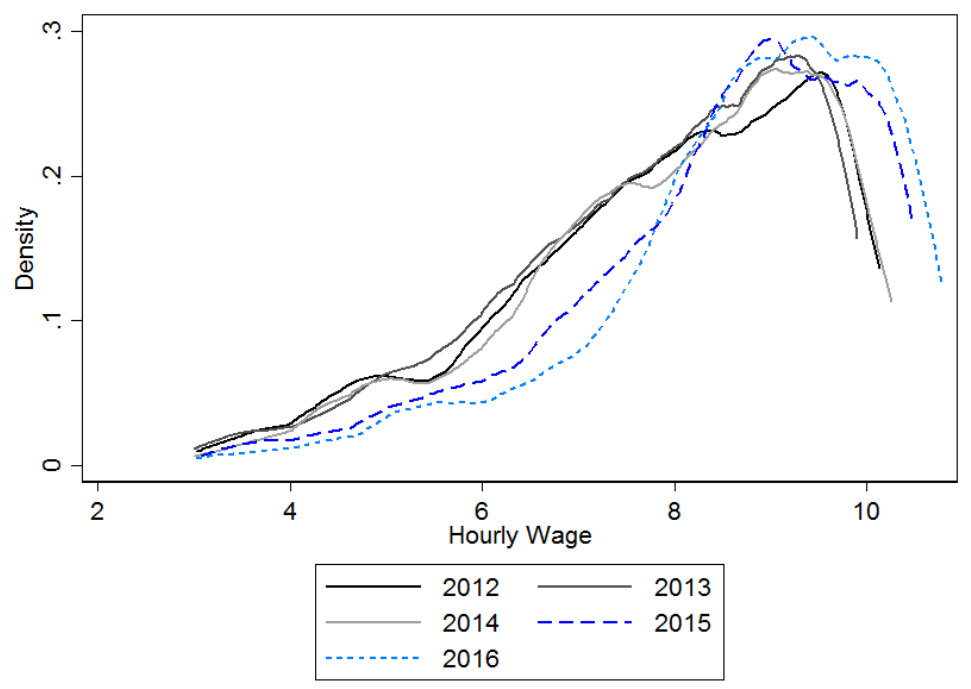

Notes: The vertical line depicts the minimum wage level of $8.50 €$ per hour. Source: SOEP, waves 2012-2016; own calculations.

Figure A5: Distributions of contractual working hours of affected employees, weighted, 2012-2016

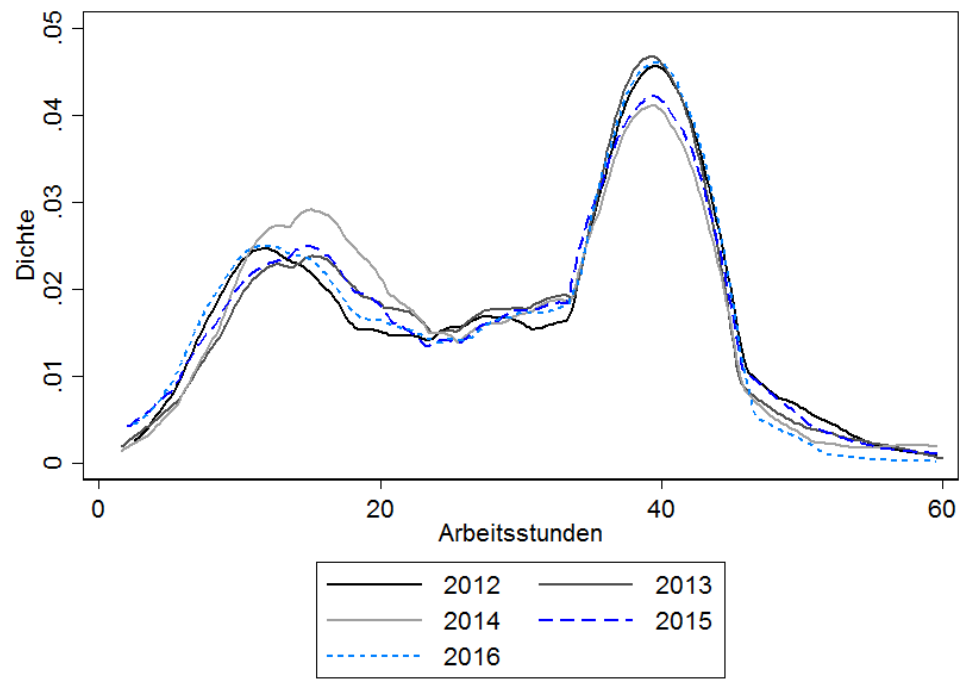

Source: SOEP, waves 2012-2016; own calculations. 


\section{Additional tables}

Table A1: Share of employees with hourly wages below $8.50 €$ per hour in \% robustness: only German citizenship

\begin{tabular}{|c|c|c|c|c|c|c|c|c|}
\hline \multirow[t]{2}{*}{ Year } & \multicolumn{4}{|c|}{ Unbalanced panel } & \multicolumn{4}{|c|}{ Balanced panel } \\
\hline & All & $\mathrm{CI}$ & eligible & CI & All & CI & eligible & CI \\
\hline 2012 & 8.5 & {$[8.0 ; 9.0]$} & 9.7 & {$[9.1 ; 10.3]$} & 5.9 & {$[5.1 ; 6.6]$} & 5.7 & {$[5.0 ; 6.5]$} \\
\hline 2013 & 8.5 & {$[8.0 ; 9.0]$} & 9.7 & {$[9.1 ; 10.3]$} & 5.6 & {$[4.9 ; 6.2]$} & 4.8 & {$[4.1 ; 5.5]$} \\
\hline 2014 & 8.1 & {$[7.6 ; 8.6]$} & 9.3 & {$[8.7 ; 9.9]$} & 4.2 & {$[3.6 ; 4.8]$} & 3.7 & {$[3.1 ; 4.3]$} \\
\hline 2015 & 5.9 & {$[5.5 ; 6.4]$} & 6.8 & {$[6.3 ; 7.4]$} & 2.5 & {$[2.1 ; 3.0]$} & 2.1 & {$[1.6 ; 2.6]$} \\
\hline 2016 & 5.4 & {$[5.0 ; 5.9]$} & 6.1 & {$[5.6 ; 6.7]$} & 2.6 & {$[2.2 ; 3.1]$} & 2.1 & {$[1.6 ; 2.5]$} \\
\hline $\mathrm{N}$ & 53,508 & & 46,843 & & 20,995 & & 18,205 & \\
\hline
\end{tabular}

Notes: The balanced panel contains 4199 observations per year and 3641 for those eligible throughout this time. Bootstrapped $95 \%$ confidence intervals (CI) in parentheses.

Source: SOEP, waves 2012-2016; own calculations.

Table A2: Share of employees with hourly wages below $8.50 €$ per hour in $\%$ robustness: only German citizenship, unweighted

\begin{tabular}{|c|c|c|c|c|c|c|c|c|}
\hline \multirow[t]{2}{*}{ Year } & \multicolumn{4}{|c|}{ Unbalanced panel } & \multicolumn{4}{|c|}{ Balanced panel } \\
\hline & All & CI & Eligible & CI & All & $\mathrm{CI}$ & Eligible & CI \\
\hline 2012 & 9.8 & {$[9.3 ; 10.4]$} & 11.2 & {$[10.6 ; 11.9]$} & 6.7 & {$[5.9 ; 7.4]$} & 6.7 & {$[5.9 ; 7.5]$} \\
\hline 2013 & 9.6 & {$[9.0,10.1]$} & 11.0 & {$[10.4 ; 11.6]$} & 6.0 & {$[5.3 ; 6.7]$} & 5.5 & {$[4.8 ; 6.2]$} \\
\hline 2014 & 8.5 & {$[8.0 ; 9.1]$} & 9.8 & {$[9.2 ; 10.4]$} & 4.7 & {$[4.1 ; 5.4]$} & 4.3 & {$[3.7 ; 5.0]$} \\
\hline 2015 & 6.3 & {$[5.9 ; 6.8]$} & 7.3 & {$[6.8 ; 7.8]$} & 3.1 & {$[2.6 ; 3.6]$} & 2.7 & {$[2.2 ; 3.2]$} \\
\hline 2016 & 5.8 & {$[5.3 ; 6.3]$} & 6.5 & {$[6.0 ; 7.0]$} & 2.8 & {$[2.3 ; 3.3]$} & 2.3 & {$[1.8 ; 2.8]$} \\
\hline $\mathrm{N}$ & 53,508 & & 46,843 & & 20,995 & & 18,205 & \\
\hline
\end{tabular}

Notes: The balanced panel contains 4199 observations per year and 3641 for those eligible throughout this time. Bootstrapped $95 \%$ confidence intervals (CI) in parentheses.

Source: SOEP, waves 2012-2016; own calculations. 
Table A3: Percentiles of the hourly wage distribution, only eligible employees robustness: only German citizenship

\begin{tabular}{|c|c|c|c|c|c|c|c|c|}
\hline \multirow[t]{3}{*}{ Year } & \multicolumn{6}{|c|}{ Percentiles } & \multicolumn{2}{|r|}{ Median } \\
\hline & \multirow[t]{2}{*}{$\mathrm{P} 1$} & \multicolumn{3}{|c|}{ P5 } & \multirow[t]{2}{*}{ P10 } & \multirow[b]{2}{*}{$\mathrm{CI}$} & \multirow{2}{*}{\multicolumn{2}{|c|}{$\mathrm{CI}$}} \\
\hline & & $\mathrm{CI}$ & & $\mathrm{CI}$ & & & & \\
\hline 2012 & 4.66 & {$[4.39 ; 4.85]$} & 7.20 & {$[6.99 ; 7.47]$} & 8.60 & {$[8.44 ; 8.74]$} & 15.54 & {$[15.17 ; 15.76]$} \\
\hline 2013 & 4.75 & {$[4.45 ; 5.20]$} & 7.20 & {$[6.99 ; 7.40]$} & 8.58 & {$[8.38 ; 8.74]$} & 15.51 & {$[15.25 ; 15.73]$} \\
\hline 2014 & 4.80 & {$[4.69 ; 5.27]$} & 7.23 & {$[7.13 ; 7.53]$} & 8.63 & {$[8.50 ; 8.84]$} & 15.97 & {$[15.75 ; 16.23]$} \\
\hline 2015 & 5.01 & {$[4.40 ; 5.48]$} & 7.99 & {$[7.58 ; 8.19]$} & 9.20 & {$[8.99 ; 9.41]$} & 16.74 & {$[16.39 ; 16.96]$} \\
\hline 2016 & 5.41 & {$[5.24 ; 6.12]$} & 8.27 & {$[8.11 ; 8.45]$} & 9.32 & {$[9.11 ; 9.53]$} & 16.78 & {$[16.35 ; 17.05]$} \\
\hline \multicolumn{9}{|c|}{ Full compliance scenario, minimum wage level: $8.50 €$ per hour } \\
\hline 2015 & 8.50 & & 8.50 & & 9.20 & {$[9.03 ; 9.36]$} & 16.74 & {$[16.51 ; 17.07]$} \\
\hline 2016 & 8.50 & & 8.50 & & 9.32 & {$[9.11 ; 9.56]$} & 16.78 & {$[16.50 ; 17.02]$} \\
\hline \multicolumn{9}{|c|}{ Full compliance scenario, minimum wage level: $12 €$ per hour } \\
\hline 2015 & 12.00 & & 12.00 & & 12.00 & & 16.74 & [16.43;17.04] \\
\hline 2016 & 12.00 & & 12.00 & & 12.00 & & 16.78 & {$[16.51 ; 17.08]$} \\
\hline
\end{tabular}

Notes: Weighted with individual frequency weights. Samples M1, M2, M3, M4 included. Bootstrapped 95\% confidence intervals (CI) in parentheses.

Source: SOEP, waves 2012-2016; own calculations.

Table A4: Percentiles of the hourly wage distribution, only eligible employees robustness: only German citizens, unweighted

\begin{tabular}{|c|c|c|c|c|c|c|c|c|}
\hline \multirow[t]{3}{*}{ Year } & \multicolumn{6}{|c|}{ Percentiles } & \multicolumn{2}{|r|}{ Median } \\
\hline & \multirow[t]{2}{*}{$\mathrm{P} 1$} & \multicolumn{3}{|c|}{ P5 } & \multirow[t]{2}{*}{ P10 } & \multirow[b]{2}{*}{$\mathrm{CI}$} & \multirow{2}{*}{\multicolumn{2}{|c|}{ CI }} \\
\hline & & CI & & $\mathrm{CI}$ & & & & \\
\hline 2012 & 4.28 & [3.99;4.66] & 6.91 & {$[6.77 ; 6.99]$} & 8.20 & {$[8.06 ; 8.38]$} & 15.36 & [15.29;15.56] \\
\hline 2013 & 4.61 & {$[4.30 ; 4.75]$} & 6.99 & {$[6.71 ; 7.02]$} & 8.29 & {$[8.16 ; 8.43]$} & 15.33 & {$[15.15 ; 15.48]$} \\
\hline 2014 & 4.72 & {$[4.61,4.85]$} & 7.13 & {$[7.02 ; 7.28]$} & 8.58 & {$[8.43 ; 8.66]$} & 15.92 & {$[15.73 ; 16.07]$} \\
\hline 2015 & 5.31 & [4.97;5.33] & 7.83 & [7.66;7.99] & 8.99 & {$[8.90 ; 9.20]$} & 16.51 & {$[16.32 ; 16.75]$} \\
\hline 2016 & 5.52 & {$[5.31 ; 5.90]$} & 8.16 & {$[8.04 ; 8.26]$} & 9.11 & {$[9.08,9.23]$} & 16.51 & {$[16.30 ; 16.78]$} \\
\hline \multicolumn{9}{|c|}{ Full compliance scenario, minimum wage level: $8.50 €$ per hour } \\
\hline 2015 & 8.50 & & 8.50 & & 8.99 & {$[8.87 ; 9.17]$} & 16.51 & {$[16.32 ; 16.76]$} \\
\hline 2016 & 8.50 & & 8.50 & & 9.11 & {$[9.05 ; 9.30]$} & 16.51 & {$[16.25 ; 16.72]$} \\
\hline \multicolumn{9}{|c|}{ Full compliance scenario, minimum wage level: $12 €$ per hour } \\
\hline 2015 & 12.00 & & 12.00 & & 12.00 & & 16.51 & [16.32;16.72] \\
\hline 2016 & 12.00 & & 12.00 & & 12.00 & & 16.51 & {$[16.30 ; 16.77]$} \\
\hline
\end{tabular}

Notes: Weighted with individual frequency weights. Samples M1,M2,M3,M4 included. Bootstrapped $95 \%$ confidence intervals $(\mathrm{CI})$ in parentheses.

Source: SOEP, waves 2012-2016; own calculations. 
Table A5: Inequality measures, poverty measures for hourly wages, only eligible employees - robustness: only German citizenship

\begin{tabular}{|c|c|c|c|c|c|c|c|c|}
\hline \multirow[t]{3}{*}{ Year } & \multirow{2}{*}{\multicolumn{2}{|c|}{$\begin{array}{l}\text { Inequality } \\
\text { Atkinson }\end{array}$}} & \multicolumn{6}{|c|}{ Poverty measures } \\
\hline & & & \multirow{2}{*}{\multicolumn{2}{|c|}{$\begin{array}{r}\text { Poverty rate } \\
\text { CI }\end{array}$}} & \multirow{2}{*}{\multicolumn{2}{|c|}{$\begin{array}{r}\text { Poverty gap } \\
\text { CI }\end{array}$}} & \multirow{2}{*}{\multicolumn{2}{|c|}{$\begin{array}{r}\text { FGT(2) } \\
\text { CI }\end{array}$}} \\
\hline & & CI & & & & & & \\
\hline 2012 & 0.20 & {$[0.18 ; 0.21]$} & 13.77 & {$[11.83 ; 15.03]$} & 2.82 & {$[2.51 ; 3.06]$} & 0.99 & {$[0.85 ; 1.10]$} \\
\hline 2013 & 0.20 & {$[0.18 ; 0.21]$} & 13.42 & {$[11.92 ; 14.84]$} & 2.75 & {$[2.47 ; 3.01]$} & 0.91 & {$[0.80 ; 1.04]$} \\
\hline 2014 & 0.20 & {$[0.19 ; 0.21]$} & 14.71 & {$[13.84 ; 15.56]$} & 2.94 & {$[2.59 ; 3.18]$} & 0.94 & {$[0.81 ; 1.08]$} \\
\hline 2015 & 0.20 & {$[0.18 ; 0.21]$} & 14.19 & {$[12.67 ; 15.15]$} & 2.72 & {$[2.34 ; 3.05]$} & 0.89 & {$[0.73 ; 1.06]$} \\
\hline 2016 & 0.19 & {$[0.18,0.21]$} & 14.15 & {$[12.90 ; 15.16]$} & 2.43 & {$[2.06 ; 2.73]$} & 0.72 & {$[0.59 ; 0.86]$} \\
\hline \multicolumn{9}{|c|}{ Full compliance scenario, minimum wage level: $8.50 €$ per hour } \\
\hline 2015 & 0.17 & {$[0.16 ; 0.18]$} & 14.19 & {$[12.99 ; 14.97]$} & 1.59 & {$[1.38 ; 1.77]$} & 0.22 & {$[0.18 ; 0.26]$} \\
\hline 2016 & 0.17 & {$[0.16 ; 0.18]$} & 14.15 & {$[12.98 ; 15.48]$} & 1.57 & {$[1.32 ; 1.74]$} & 0.21 & {$[0.16 ; 0.25]$} \\
\hline \multicolumn{9}{|c|}{ Full compliance scenario, minimum wage level: $12 €$ per hour } \\
\hline 2015 & 0.13 & {$[0.12 ; 0.14]$} & 0.00 & & 0.00 & & 0.00 & \\
\hline 2016 & 0.13 & {$[0.11 ; 0.14]$} & 0.00 & & 0.00 & & 0.00 & \\
\hline
\end{tabular}

Notes: Poverty line at $60 \%$ of median wage. FGT(2) and FGT(3) denote $F G T(\alpha)=\frac{1}{n} \sum_{i=1}^{q}\left(\frac{z-y_{i}}{z}\right)^{\alpha}$ for $z:=$ poverty line and $q:=$ number of poor, with $\alpha=2$ and $\alpha=3$ respectively. Weighted with individual frequency weights. Samples M1,M2, M3,M4 included. Bootstrapped 95\% confidence intervals (CI) in parentheses.

Source: SOEP, waves 2012-2016; own calculations.

Table A6: Inequality measures, poverty measures for hourly wages, only eligible employees - robustness: only German citizenship, unweighted

\begin{tabular}{|c|c|c|c|c|c|c|c|c|}
\hline \multirow{4}{*}{$\begin{array}{l}\text { Year } \\
2012\end{array}$} & \multirow{3}{*}{\multicolumn{2}{|c|}{$\begin{array}{r}\text { Inequality } \\
\text { Atkinson } \\
\text { CI }\end{array}$}} & \multicolumn{6}{|c|}{ Poverty measures } \\
\hline & & & \multirow{2}{*}{\multicolumn{2}{|c|}{$\begin{array}{r}\text { Poverty rate } \\
\text { CI }\end{array}$}} & \multirow{2}{*}{\multicolumn{2}{|c|}{$\begin{array}{r}\text { Poverty gap } \\
\text { CI }\end{array}$}} & \multirow{2}{*}{\multicolumn{2}{|c|}{$\begin{array}{r}\text { FGT(2) } \\
\text { CI }\end{array}$}} \\
\hline & & & & & & & & \\
\hline & 0.22 & {$[0.21 ; 0.23]$} & 14.05 & {$[13.61 ; 15.43]$} & 3.23 & {$[3.04 ; 3.41]$} & 1.16 & {$[1.04 ; 1.26]$} \\
\hline 2013 & 0.22 & {$[0.21 ; 0.23]$} & 13.92 & {$[13.29 ; 14.62]$} & 3.05 & {$[2.87 ; 3.21]$} & 1.05 & {$[0.96 ; 1.14]$} \\
\hline 2014 & 0.22 & {$[0.21 ; 0.22]$} & 15.20 & {$[14.53 ; 15.65]$} & 3.12 & {$[2.93 ; 3.25]$} & 1.04 & {$[0.94 ; 1.11]$} \\
\hline 2015 & 0.20 & {$[0.19 ; 0.21]$} & 14.00 & {$[13.02 ; 15.17]$} & 2.71 & {$[2.45 ; 2.94]$} & 0.84 & {$[0.75 ; 0.95]$} \\
\hline 2016 & 0.20 & {$[0.19 ; 0.21]$} & 14.19 & {$[13.35 ; 15.03]$} & 2.41 & {$[2.21 ; 2.60]$} & 0.71 & {$[0.62 ; 0.79]$} \\
\hline \multicolumn{9}{|c|}{ Full compliance scenario, minimum wage level: $8.50 €$ per hour } \\
\hline 2015 & 0.18 & {$[0.17 ; 0.19]$} & 14.00 & {$[13.07 ; 15.11]$} & 1.54 & {$[1.36 ; 1.70]$} & 0.20 & {$[0.16 ; 0.23]$} \\
\hline 2016 & 0.18 & {$[0.17 ; 0.18]$} & 14.19 & {$[13.32 ; 15.08]$} & 1.47 & {$[1.27 ; 1.64]$} & 0.18 & {$[0.15 ; 0.22]$} \\
\hline \multicolumn{9}{|c|}{ Full compliance scenario, minimum wage level: $12 €$ per hour } \\
\hline 2015 & 0.13 & {$[0.13 ; 0.14]$} & 0.00 & & 0.00 & & 0.00 & \\
\hline 2016 & 0.13 & {$[0.13 ; 0.14]$} & 0.00 & & 0.00 & & 0.00 & \\
\hline
\end{tabular}

Notes: Poverty line at $60 \%$ of median wage. FGT(2) and FGT(3) denote $F G T(\alpha)=\frac{1}{n} \sum_{i=1}^{q}\left(\frac{z-y_{i}}{z}\right)^{\alpha}$ for $z:=$ poverty line and $q:=$ number of poor, with $\alpha=2$ and $\alpha=3$ respectively. Weighted with individual frequency weights. Samples M1, M2, M3, M4 included. Bootstrapped 95\% confidence intervals (CI) in parentheses.

Source: SOEP, waves 2012-2016; own calculations. 
Table A7: Percentiles of monthly disposable household equivalence income in $€-$ robustness: only German citizenship

\begin{tabular}{lcccccccccr}
\hline \hline Year & P5 & \multicolumn{3}{c}{ P10 } & \multicolumn{3}{c}{ Mean } & \multicolumn{2}{c}{ Median } & N \\
& \multicolumn{1}{c}{ CI } & \multicolumn{2}{c}{ CI } & & CI & & CI & \\
\hline 2012 & 626 & {$[602 ; 642]$} & 714 & {$[695 ; 729]$} & 1838 & {$[1797 ; 1915]$} & 1519 & {$[1480 ; 1547]$} & 10,693 \\
2013 & 636 & {$[622 ; 648]$} & 721 & {$[707 ; 738]$} & 1879 & {$[1835 ; 1929]$} & 1534 & {$[1505 ; 1566]$} & 10,829 \\
2014 & 665 & {$[651 ; 673]$} & 740 & {$[726 ; 759]$} & 1949 & {$[1883 ; 2017]$} & 1592 & {$[1548 ; 1632]$} & 9,445 \\
2015 & 664 & {$[639 ; 677]$} & 758 & {$[740 ; 772]$} & 1979 & {$[1918 ; 2051]$} & 1620 & {$[1587 ; 1660]$} & 8,746 \\
2016 & 658 & {$[643 ; 671]$} & 760 & {$[728 ; 789]$} & 2187 & {$[2105 ; 2281]$} & 1729 & {$[1678 ; 1783]$} & 7,382 \\
Full compliance scenario, minimum wage level: $8.50 €$ per hour & & & \\
2015 & 667 & {$[639 ; 678]$} & 760 & {$[735 ; 776]$} & 1986 & {$[1928 ; 2060]$} & 1631 & {$[1582 ; 1663]$} & 8,746 \\
2016 & 658 & {$[646 ; 674]$} & 769 & {$[734 ; 791]$} & 2191 & {$[2107 ; 2288]$} & 1733 & {$[1691 ; 1785]$} & 7,382 \\
Full compliance scenario, minimum wage level: $12 €$ per hour & & & \\
2015 & 668 & {$[645 ; 682]$} & 764 & {$[741 ; 779]$} & 2007 & {$[1944 ; 2078]$} & 1655 & {$[1618 ; 1692]$} & 8,746 \\
2016 & 658 & {$[645 ; 674]$} & 772 & {$[738 ; 802]$} & 2210 & {$[2118 ; 2312]$} & 1767 & {$[1718 ; 1811]$} & 7,382 \\
\hline \hline
\end{tabular}

Notes: Equivalence weights according to the new OECD scale. Weighted with household frequency weights. Bootstrapped 95\% confidence intervals (CI) in parentheses.

Source: SOEP, waves 2012-2016; own calculations.

Table A8: Percentiles of monthly disposable household equivalence income in $€$ robustness: only German citizenship, unweighted

\begin{tabular}{lllllllllr}
\hline \hline Year & P5 & \multicolumn{3}{c}{ P10 } & \multicolumn{3}{c}{ Mean } & Median & N \\
\hline 2012 & 661 & {$[653 ; 669]$} & 769 & {$[762 ; 779]$} & 1775 & {$[1754 ; 1813]$} & 1397 & {$[1383 ; 1419]$} & 10,693 \\
2013 & 676 & {$[664 ; 683]$} & 785 & {$[770 ; 793]$} & 1815 & {$[1778 ; 1843]$} & 1443 & {$[1421 ; 1465]$} & 10,829 \\
2014 & 687 & {$[674 ; 696]$} & 806 & {$[787 ; 817]$} & 1890 & {$[1850 ; 1927]$} & 1518 & {$[1494 ; 1544]$} & 9,445 \\
2015 & 696 & {$[684 ; 710]$} & 813 & {$[799 ; 827]$} & 1913 & {$[1879 ; 1950]$} & 1554 & {$[1525 ; 1575]$} & 8,746 \\
2016 & 704 & {$[693 ; 713]$} & 843 & {$[828 ; 858]$} & 2265 & {$[2206 ; 2328]$} & 1738 & {$[1704 ; 1773]$} & 7,382 \\
Full compliance scenario, minimum wage level: $8.50 €$ per hour & & & \\
2015 & 700 & {$[683 ; 709]$} & 818 & {$[804 ; 829]$} & 1919 & {$[1877 ; 1965]$} & 1561 & {$[1533 ; 1580]$} & 8,746 \\
2016 & 704 & {$[691 ; 719]$} & 852 & {$[833 ; 870]$} & 2269 & {$[2218 ; 2328]$} & 1741 & {$[1702 ; 1777]$} & 7,382 \\
Full compliance scenario, minimum wage level: $12 €$ per hour & & & \\
2015 & 704 & {$[690 ; 713]$} & 821 & {$[809 ; 834]$} & 1938 & {$[1892 ; 1982]$} & 1589 & {$[1565 ; 1606]$} & 8,746 \\
2016 & 708 & {$[694 ; 719]$} & 856 & {$[839 ; 871]$} & 2288 & {$[2249 ; 2337]$} & 1776 & {$[1744 ; 1804]$} & 7,382 \\
\hline \hline
\end{tabular}

Notes: Equivalence weights according to the new OECD scale Household frequency weights by SOEP. Bootstrapped 95\% confidence intervals (CI) in parentheses.

Source: SOEP, waves 2012-2016; all samples included, own calculations. 
Table A9: Inequality measures, poverty measures of net household income robustness: fixed poverty line (whole sample with weights)

\begin{tabular}{|c|c|c|c|c|c|c|c|}
\hline \multirow[t]{3}{*}{ Year } & \multicolumn{6}{|c|}{ Poverty measures } & \multirow{3}{*}{$\begin{array}{c}\text { Poverty } \\
\text { line }\end{array}$} \\
\hline & \multirow{2}{*}{\multicolumn{2}{|c|}{ Poverty rate }} & \multicolumn{2}{|c|}{ Poverty gap } & \multirow{2}{*}{\multicolumn{2}{|c|}{ FGT(2) }} & \\
\hline & & & & CI & & & \\
\hline 20123 & 22.71 & {$[20.63 ; 24.67]$} & 5.63 & {$[5.00 ; 6.25]$} & 2.40 & {$[2.05 ; 2.75]$} & 928.17 \\
\hline 2013 & 23.01 & {$[20.84 ; 25.04]$} & 5.43 & {$[4.85 ; 6.07]$} & 2.21 & {$[1.91 ; 2.54]$} & 928.17 \\
\hline 2014 & 21.04 & {$[19.34 ; 22.31]$} & 5.04 & [4.56;5.51] & 2.20 & {$[1.90 ; 2.53]$} & 928.17 \\
\hline 2015 & 21.21 & [18.91;23.53] & 4.95 & [4.31;5.66] & 2.12 & {$[1.78 ; 2.50]$} & 928.17 \\
\hline 2016 & 19.44 & {$[17.38 ; 21.25]$} & 4.63 & {$[4.02 ; 5.22]$} & 1.98 & {$[1.65 ; 2.38]$} & 928.17 \\
\hline \multicolumn{8}{|c|}{ Full compliance scenario, minimum wage level: $8.50 €$ per hour } \\
\hline 2015 & 20.29 & {$[18.16 ; 22.13]$} & 4.80 & {$[4.21 ; 5.39]$} & 2.06 & [1.72;2.39] & 928.17 \\
\hline 2016 & 18.83 & {$[16.88 ; 20.60]$} & 4.51 & {$[3.90 ; 5.08]$} & 1.94 & {$[1.61 ; 2.29]$} & 928.17 \\
\hline \multicolumn{8}{|c|}{ Full compliance scenario, minimum wage level: $12 €$ per hour } \\
\hline 2015 & 19.51 & {$[17.58 ; 21.35]$} & $4.71^{\circ}$ & {$[4.14 ; 5.33]$} & 2.03 & {$[1.72 ; 2.39]$} & 928.17 \\
\hline 2016 & 18.28 & {$[16.29 ; 19.91]$} & 4.42 & [3.84;5.04] & 1.91 & {$[1.58 ; 2.30]$} & 928.17 \\
\hline
\end{tabular}

Notes: Equivalence weights according to the new OECD scale. Household frequency weights used. Poverty rate kept fix on 2014 level. $F G T(\alpha)=\frac{1}{n} \sum_{i=1}^{q}\left(\frac{z-y_{i}}{z}\right)^{\alpha}$ for $z:=$ poverty line and $q:=$ number of poor. Bootstrapped $95 \%$ confidence intervals $(\mathrm{CI})$ in parentheses.

Source: SOEP, waves 2012-2016; own calculations.

Table A10: Inequality and poverty measures of net household income - robustness: only German citizenship

\begin{tabular}{|c|c|c|c|c|c|c|c|c|c|}
\hline \multirow[t]{3}{*}{ Year } & \multicolumn{2}{|c|}{ Inequality } & \multicolumn{4}{|c|}{ Poverty measures } & & & \multirow{3}{*}{$\begin{array}{l}\text { Poverty } \\
\text { line }\end{array}$} \\
\hline & \multirow{2}{*}{\multicolumn{2}{|c|}{ Atkinson }} & \multicolumn{2}{|c|}{ Poverty rate } & \multicolumn{2}{|c|}{ Poverty gap } & \multicolumn{2}{|c|}{ FGT(2) } & \\
\hline & & & & $\mathrm{CI}$ & & CI & & CI & \\
\hline 2012 & 0.55 & {$[0.44 ; 0.66]$} & 21.4 & {$[20.1 ; 22.2]$} & 5.4 & {$[4.9 ; 5.8]$} & 2.3 & {$[2.1 ; 2.7]$} & 911.7 \\
\hline 2013 & 0.46 & {$[0.41 ; 0.51]$} & 21.9 & {$[20.8 ; 23.3]$} & 5.2 & {$[4.8 ; 5.7]$} & 2.2 & {$[1.9 ; 2.5]$} & 920.1 \\
\hline 2014 & 0.51 & {$[0.45 ; 0.57]$} & 21.9 & {$[20.7 ; 23.3]$} & 5.4 & {$[4.8 ; 5.9]$} & 2.3 & {$[1.9 ; 2.7]$} & 955.0 \\
\hline 2015 & 0.48 & {$[0.42 ; 0.54]$} & 23.0 & {$[21.9 ; 24.5]$} & 5.6 & {$[5.1 ; 6.1]$} & 2.4 & {$[2.0 ; 2.7]$} & 972.1 \\
\hline 2016 & 0.53 & {$[0.47 ; 0.60]$} & 23.6 & {$[22.5 ; 25.3]$} & 6.3 & {$[5.8 ; 6.9]$} & 2.7 & {$[2.4 ; 3.1]$} & 1037.5 \\
\hline \multicolumn{10}{|c|}{ Full compliance scenario, minimum wage level: $8.50 €$ per hour } \\
\hline 2015 & 0.48 & {$[0.42 ; 0.54]$} & 22.4 & [21.0;23.7] & 5.5 & {$[5.1 ; 6.0]$} & 2.3 & {$[2.1 ; 2.7]$} & 978.5 \\
\hline 2016 & 0.53 & {$[0.47 ; 0.59]$} & 23.2 & {$[22.1 ; 24.7]$} & 6.2 & {$[5.6 ; 6.8]$} & 2.7 & {$[2.3 ; 3.1]$} & 1039.8 \\
\hline \multicolumn{10}{|c|}{ Full compliance scenario, minimum wage level: $12 €$ per hour } \\
\hline 2015 & 0.48 & {$[0.41 ; 0.55]$} & 22.2 & {$[21.1 ; 23.4]$} & 5.6 & {$[5.2 ; 6.1]$} & 2.4 & {$[2.1 ; 2.7]$} & 993.2 \\
\hline 2016 & 0.53 & {$[0.47 ; 0.60]$} & 23.4 & [22.0;24.6] & 6.3 & {$[5.8 ; 6.8]$} & 2.7 & {$[2.4 ; 3.1]$} & 1060.1 \\
\hline
\end{tabular}

Notes: Equivalence weights according to the new OECD scale. Poverty rate determined by year. $F G T(\alpha)=\frac{1}{n} \sum_{i=1}^{q}\left(\frac{z-y_{i}}{z}\right)^{\alpha}$ for $z:=$ poverty line and $q:=$ number of poor. Weighted with household frequency weights. Bootstrapped $95 \%$ confidence intervals (CI) in parentheses.

Source: SOEP, waves 2012-2016; own calculations. 
Table A11: Inequality and poverty measures of net household income robustness: only German citizens, unweighted

\begin{tabular}{|c|c|c|c|c|c|c|c|c|c|}
\hline \multirow[t]{3}{*}{ Year } & \multicolumn{2}{|c|}{ Inequality } & \multicolumn{6}{|c|}{ Poverty measures } & \multirow{3}{*}{$\begin{array}{r}\text { Poverty } \\
\text { line }\end{array}$} \\
\hline & \multicolumn{2}{|c|}{ Atkinson } & \multicolumn{2}{|c|}{ Poverty rate } & \multicolumn{2}{|c|}{ Poverty gap } & \multicolumn{2}{|c|}{$\mathrm{FGT}(2)$} & \\
\hline & & $\mathrm{CI}$ & & $\mathrm{CI}$ & & $\mathrm{CI}$ & & $\mathrm{CI}$ & \\
\hline 2012 & 0.47 & {$[0.39 ; 0.59]$} & 14.0 & {$[13.3 ; 14.8]$} & 3.1 & {$[2.8 ; 3.3]$} & 1.3 & {$[1.2 ; 1.5]$} & 838.3 \\
\hline 2013 & 0.39 & {$[0.36 ; 0.42]$} & 14.8 & {$[14.2 ; 15.8]$} & 3.1 & {$[3.0 ; 3.4]$} & 1.3 & {$[1.2 ; 1.5]$} & 865.8 \\
\hline 2014 & 0.41 & {$[0.37 ; 0.45]$} & 16.2 & {$[15.1 ; 17.1]$} & 3.4 & {$[3.2 ; 3.7]$} & 1.4 & {$[1.2 ; 1.6]$} & 911.0 \\
\hline 2015 & 0.40 & {$[0.35 ; 0.43]$} & 17.1 & {$[16.0 ; 18.4]$} & 3.6 & {$[3.4 ; 3.9]$} & 1.5 & {$[1.3 ; 1.7]$} & 932.5 \\
\hline 2016 & 0.49 & {$[0.44 ; 0.53]$} & 20.2 & {$[19.5 ; 21.2]$} & 4.8 & {$[4.5 ; 5.1]$} & 1.9 & {$[1.8 ; 2.1]$} & 1042.8 \\
\hline \multicolumn{10}{|c|}{ Full compliance scenario, minimum wage level: $8.50 €$ per hour } \\
\hline 2015 & 0.40 & {$[0.37 ; 0.43]$} & 16.8 & {$[15.7 ; 17.7]$} & 3.6 & {$[3.3 ; 3.9]$} & 1.5 & {$[1.3 ; 1.6]$} & 936.5 \\
\hline 2016 & 0.48 & {$[0.44 ; 0.53]$} & 19.8 & {$[18.9 ; 20.7]$} & 4.7 & {$[4.4 ; 5.1]$} & 1.9 & {$[1.7 ; 2.1]$} & 1044.6 \\
\hline \multicolumn{10}{|c|}{ Full compliance scenario, minimum wage level: $12 €$ per hour } \\
\hline 2015 & 0.40 & {$[0.36 ; 0.45]$} & 17.3 & {$[16.4 ; 18.1]$} & 3.7 & {$[3.5 ; 4.0]$} & 1.5 & {$[1.4 ; 1.7]$} & 953.1 \\
\hline 2016 & 0.48 & {$[0.44 ; 0.52]$} & 20.1 & {$[19.2 ; 21.1]$} & 4.9 & {$[4.6 ; 5.2]$} & 2.0 & {$[1.8 ; 2.2]$} & 1065.3 \\
\hline
\end{tabular}

Notes: Equivalence weights according to the new OECD scale. Household frequency weights by SOEP. Bootstrapped $95 \%$ confidence intervals (CI) in parentheses. Poverty rate determined by year. $F G T(\alpha)=$ $\frac{1}{n} \sum_{i=1}^{q}\left(\frac{z-y_{i}}{z}\right)^{\alpha}$ for $z:=$ poverty line and $q:=$ number of poor.

Source: SOEP, waves 2012-2016; own calculations.

Table A12: Inequality measures, poverty measures of net household income robustness: fixed poverty line (only german citizens no weights)

\begin{tabular}{|c|c|c|c|c|c|c|c|}
\hline \multirow[t]{3}{*}{ Year } & \multicolumn{6}{|c|}{ Poverty measures } & \multirow{3}{*}{$\begin{array}{c}\text { Poverty } \\
\text { line }\end{array}$} \\
\hline & \multirow{2}{*}{\multicolumn{2}{|c|}{ Poverty rate }} & \multicolumn{2}{|c|}{ Poverty gap } & \multirow{2}{*}{\multicolumn{2}{|c|}{ FGT(2) }} & \\
\hline & & & & CI & & & \\
\hline 2012 & 19.25 & [17.73;20.39] & 4.14 & {$[3.77 ; 4.43]$} & 1.68 & {$[1.53 ; 1.84]$} & 911.04 \\
\hline 2013 & 18.31 & [17.27;19.85] & 3.80 & {$[3.55 ; 4.14]$} & 1.51 & {$[1.36 ; 1.66]$} & 911.04 \\
\hline 2014 & 16.20 & {$[15.07 ; 17.10]$} & 3.45 & {$[3.21 ; 3.75]$} & 1.40 & [1.25;1.56] & 911.04 \\
\hline 2015 & 15.48 & {$[14.11 ; 16.77]$} & 3.33 & [2.98;3.66] & 1.38 & {$[1.19 ; 1.57]$} & 911.04 \\
\hline 2016 & 13.29 & [12.37;14.95] & 3.04 & {$[2.82 ; 3.39]$} & 1.33 & {$[1.19 ; 1.57]$} & 911.04 \\
\hline \multicolumn{8}{|c|}{ Full compliance scenario, minimum wage level: $8.50 €$ per hour } \\
\hline 2015 & 14.91 & [13.73;16.28] & 3.25 & {$[2.96 ; 3.57]$} & 1.35 & {$[1.18 ; 1.53]$} & 911.04 \\
\hline 2016 & 12.87 & [11.95;14.28] & 2.97 & {$[2.70 ; 3.32]$} & 1.31 & {$[1.14 ; 1.51]$} & 911.04 \\
\hline \multicolumn{8}{|c|}{ Full compliance scenario, minimum wage level: $12 €$ per hour } \\
\hline 2015 & 14.43 & {$[13.19 ; 15.81]$} & 3.19 & {$[2.92 ; 3.49]$} & 1.33 & {$[1.17 ; 1.53]$} & 911.04 \\
\hline 2016 & 12.40 & {$[11.32 ; 13.70]$} & 2.90 & {$[2.62 ; 3.22]$} & 1.29 & {$[1.10 ; 1.49]$} & 911.04 \\
\hline
\end{tabular}

Notes: Equivalence weights according to the new OECD scale. Household frequency weights used by SOEP. Bootstrapped $95 \%$ confidence intervals (CI) in parentheses. Poverty rate kept fix on 2014 level. $F G T(\alpha)=\frac{1}{n} \sum_{i=1}^{q}\left(\frac{z-y_{i}}{z}\right)^{\alpha}$ for $z:=$ poverty line and $q:=$ number of poor.

Source: SOEP, waves 2012-2016; own calculations. 


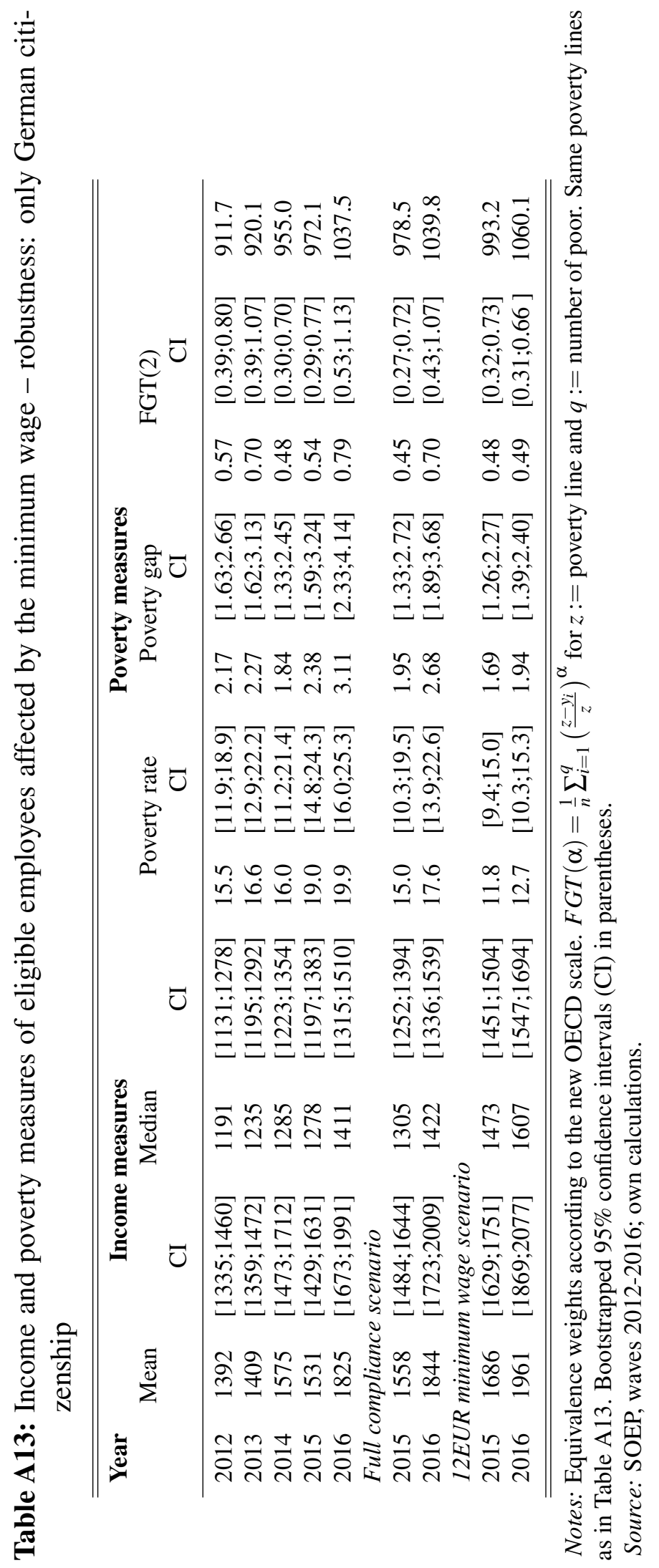




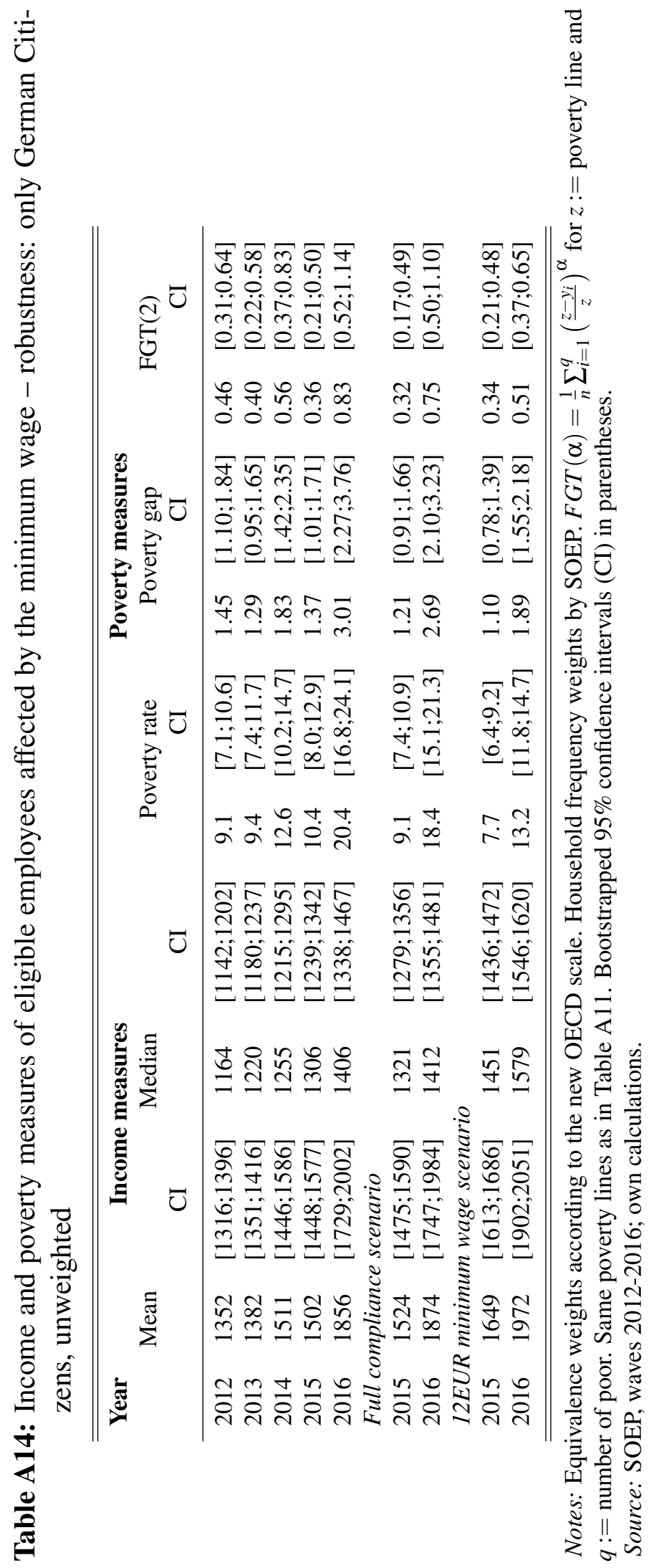


Table A15: Top-up benefits and welfare receipt - robustness: only German citizenship

\begin{tabular}{|c|c|c|c|c|c|c|}
\hline \multirow[t]{2}{*}{ Year } & \multicolumn{2}{|c|}{ Eligible for top-up benefits (\%) } & \multicolumn{4}{|c|}{ Social assistance transfer $€$ per year } \\
\hline & & $\mathrm{CI}$ & eligibility & $\mathrm{CI}$ & take-up & CI \\
\hline 2012 & 10.3 & {$[9.4 ; 11.1]$} & 1871.5 & {$[1769.7 ; 1956.1]$} & 675.5 & [626.8;729.1] \\
\hline 2013 & 10.7 & {$[9.9 ; 11.4]$} & 1995.0 & [1876.6;2147.5] & 714.4 & [658.9;779.8] \\
\hline 2014 & 11.0 & {$[10.2 ; 12.2]$} & 1876.1 & {$[1782.3 ; 2020.8]$} & 740.1 & [645.3;839.8] \\
\hline 2015 & 10.0 & {$[8.9 ; 11.2]$} & 1937.7 & [1807.2;2071.6] & 687.4 & {$[598.7 ; 772.3]$} \\
\hline 2016 & 9.8 & {$[8.7 ; 11.0]$} & 1808.3 & [1692.3;1960.7] & 748.1 & [663.9;833.1] \\
\hline \multicolumn{7}{|c|}{ Full compliance scenario, minimum wage level: $8.50 €$ per hour } \\
\hline 2015 & 9.2 & {$[8.3 ; 10.2]$} & 1858.9 & {$[1754.6 ; 1965.7]$} & & \\
\hline 2016 & 9.3 & {$[8.4 ; 10.1]$} & 1754.2 & {$[1645.7 ; 1878.9]$} & & \\
\hline \multicolumn{7}{|c|}{ Full compliance scenario, minimum wage level: $12 €$ per hour } \\
\hline 2015 & 8.1 & {$[7.2 ; 8.8]$} & 1777.2 & {$[1646.3,1950.3]$} & & \\
\hline 2016 & 8.3 & {$[7.5 ; 9.5]$} & 1681.1 & {$[1570.4 ; 1828.5]$} & & \\
\hline
\end{tabular}

Notes: Equivalence weights according to the new OECD scale. Household frequency weights by SOEP. Bootstrapped $95 \%$ confidence intervals (CI) in parentheses.

Source: SOEP, waves 2012-2015; own calculations.

Table A16: Top-up benefits and welfare receipt - robustness: only German citizens, unweighted

\begin{tabular}{|c|c|c|c|c|c|c|}
\hline \multirow[t]{2}{*}{ Year } & \multicolumn{2}{|c|}{ Eligible for top-up benefits (\%) } & \multicolumn{4}{|c|}{ Social assistance transfer $€$ per year } \\
\hline & & $\mathrm{CI}$ & eligibility & $\mathrm{CI}$ & take-up & CI \\
\hline 2012 & 13.8 & {$[13.1 ; 14.4]$} & 2426.4 & {$[2334.1,2516.7]$} & 917.2 & {$[875.2 ; 974.6]$} \\
\hline 2013 & 14.1 & {$[13.5 ; 14.8]$} & 2458.7 & {$[2350.5,2554.9]$} & 981.8 & [920.6;1044.4] \\
\hline 2014 & 13.3 & {$[12.7 ; 14.0]$} & 2251.3 & [2154.4;2353.2] & 912.3 & {$[851.3 ; 970.7]$} \\
\hline 2015 & 11.9 & {$[11.3 ; 12.6]$} & 2335.9 & {$[2229.7,2415.2]$} & 895.0 & [826.7;951.7] \\
\hline 2016 & 10.9 & {$[10.0 ; 11.6]$} & 1944.1 & [1857.2;2043.9] & 842.6 & [771.8;904.1] \\
\hline \multicolumn{7}{|c|}{ Full compliance scenario, minimum wage level: $8.50 €$ per hour } \\
\hline 2015 & 11.4 & {$[10.6 ; 12.0]$} & 2256.0 & {$[2156.5,2340.4]$} & & \\
\hline 2016 & 10.5 & {$[9.8 ; 11.2]$} & 1894.2 & [1824.1;1983.6] & & \\
\hline \multicolumn{7}{|c|}{ Full compliance scenario, minimum wage level: $12 €$ per hour } \\
\hline 2015 & 9.9 & {$[9.3,10.5]$} & 2133.9 & [2048.1;2238.2] & & \\
\hline 2016 & 9.4 & {$[8.7 ; 10.1]$} & 1787.6 & {$[1715.9 ; 1886.9]$} & & \\
\hline
\end{tabular}

Notes: Equivalence weights according to the new OECD scale. Household frequency weights by SOEP. Bootstrapped $95 \%$ confidence intervals (CI) in parentheses.

Source: SOEP, waves 2012-2015; own calculations. 


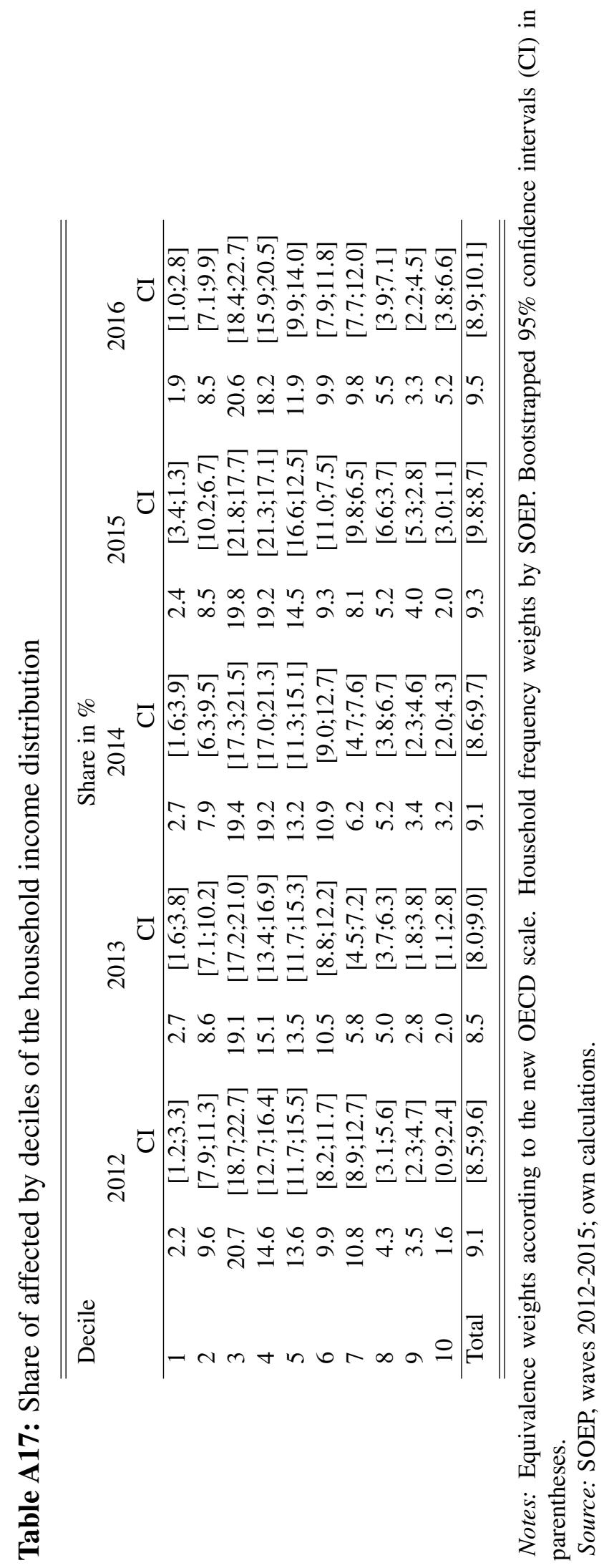




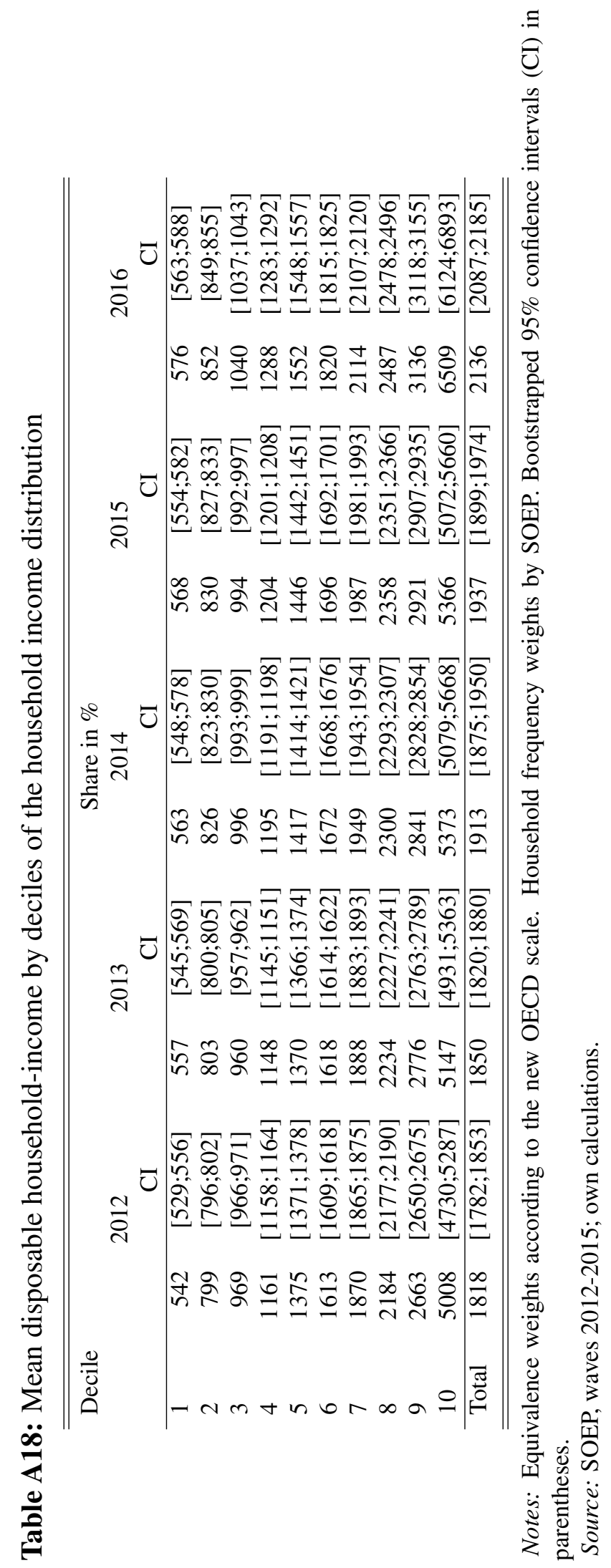




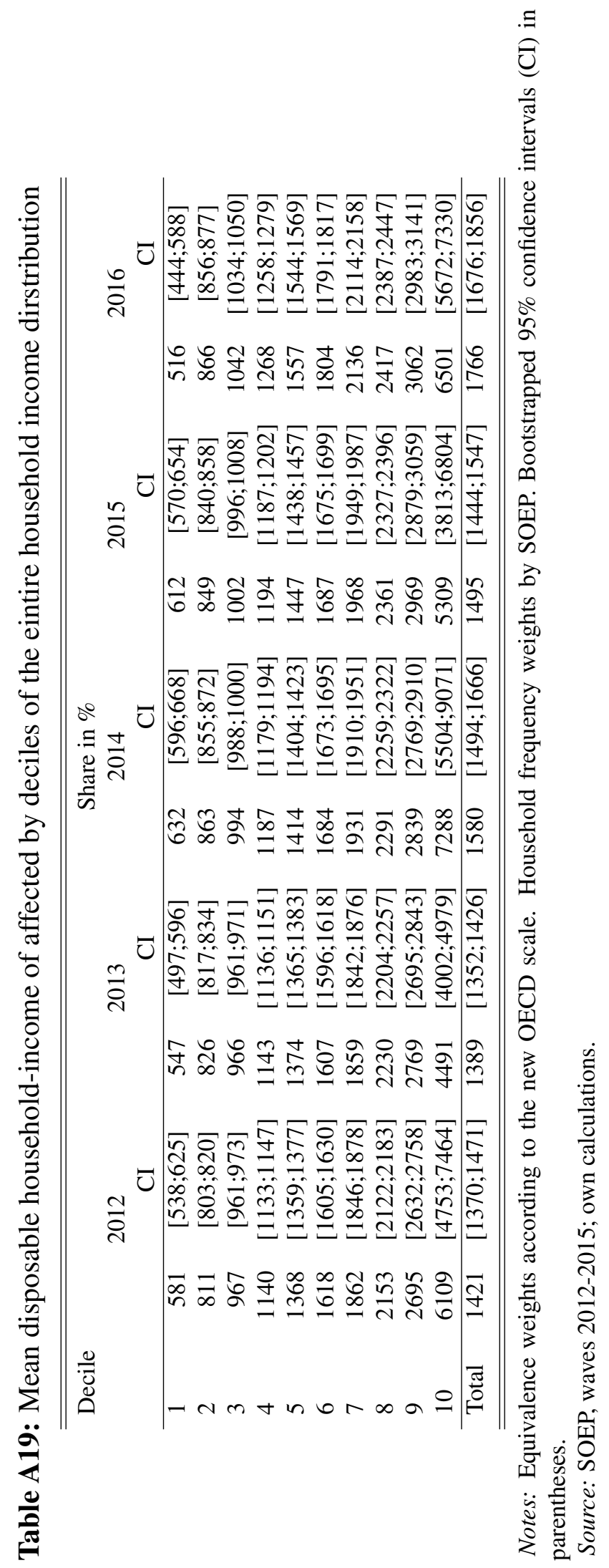


Table A20: Eligible individuals in the bottom $11 \%$ of the hourly wage distribution robustness: unweighted

\begin{tabular}{lrrrrr}
\hline \hline & $\mathbf{2 0 1 2}$ & $\mathbf{2 0 1 3}$ & $\mathbf{2 0 1 4}$ & $\mathbf{2 0 1 5}$ & $\mathbf{2 0 1 6}$ \\
\hline Threshold wage in $€$ & 8.37 & 8.64 & 8.81 & 9.32 & 9.32 \\
\hline Employment categories & in $\%$ & & & & \\
- full time & 46.2 & 46.9 & 47.5 & 48.7 & 43.1 \\
- part time & 14.2 & 15.5 & 16.3 & 16.54 & 18.0 \\
- marginal & 28.3 & 24.3 & 26.0 & 23.6 & 20.2 \\
\hline Contractual working hours per week & & & \\
- mean & 28.5 & 28.6 & 28.1 & 28.7 & 28.3 \\
- median & 29.5 & 29.5 & 29.5 & 29.5 & 30.5 \\
\hline Sectors (in \%) & & & & & \\
Agriculture & 1.7 & 1.6 & 1.5 & 1.8 & 0.5 \\
Energy & 0.6 & 0.6 & 0.5 & 0.5 & 0.2 \\
Manufacturing & 14.2 & 14.6 & 12.4 & 12.2 & 12.1 \\
Construction & 5.2 & 5.3 & 3.8 & 4.8 & 6.1 \\
Trade & 30.4 & 31.9 & 28.7 & 31.2 & 26.6 \\
Transport & 4.8 & 5.2 & 4.2 & 6.2 & 6.1 \\
Bank, Insurance & 1.3 & 1.1 & 1.3 & 0.5 & 0.7 \\
Services & 37.5 & 39.0 & 41.4 & 38.7 & 40.2 \\
\hline Observations & 1166 & 1097 & 991 & 937 & 821 \\
\hline \hline
\end{tabular}

Notes: Affected individuals: bottom $11 \%$ of the hourly wage distribution - reference: share of individuals who earned less than $8.50 €$ per hour in 2013.

Source: SOEP, waves 2012-2016; own calculations. 